NBER WORKING PAPER SERIES

\title{
PARENTAL BELIEFS ABOUT RETURNS TO DIFFERENT TYPES OF INVESTMENTS IN SCHOOL CHILDREN
}

\author{
Orazio Attanasio \\ Teodora Boneva \\ Christopher Rauh \\ Working Paper 25513 \\ http://www.nber.org/papers/w25513 \\ NATIONAL BUREAU OF ECONOMIC RESEARCH \\ 1050 Massachusetts Avenue \\ Cambridge, MA 02138 \\ January 2019
}

This project has been funded by the Nuffield Foundation (EDU/42718) and it has been approved by the UCL Research Ethics Committee (Project ID number: 9287/001). We are grateful to Akash Raja and Jack Light for excellent research assistance. We thank Flavio Cunha, Armin Falk and Costas Meghir as well as seminar participants at the University College Dublin for providing us with valuable comments. Boneva acknowledges financial support from the British Academy and the Jacobs Foundation. While this project was funded by the Nuffield Foundation the views expressed are those of the authors and not necessarily those of the Foundation. The views expressed herein are those of the authors and do not necessarily reflect the views of the National Bureau of Economic Research.

NBER working papers are circulated for discussion and comment purposes. They have not been peer-reviewed or been subject to the review by the NBER Board of Directors that accompanies official NBER publications.

(C) 2019 by Orazio Attanasio, Teodora Boneva, and Christopher Rauh. All rights reserved. Short sections of text, not to exceed two paragraphs, may be quoted without explicit permission provided that full credit, including $(\odot$ notice, is given to the source. 
Parental Beliefs about Returns to Different Types of Investments in School Children

Orazio Attanasio, Teodora Boneva, and Christopher Rauh

NBER Working Paper No. 25513

January 2019

JEL No. I24,I26,J13,J24,J62

\begin{abstract}
$\underline{\text { ABSTRACT }}$
Parental investments as well as school quality are important determinants of children's later-life outcomes. In this paper, we shed light on what determines parental investments and study how parents perceive the returns to parental time investments, material investments and school quality, as well as the complementarity/substitutability between the different inputs. Using a representative sample of 1,962 parents in England, we document that parents perceive the returns to 3 hours of weekly parental time investments or $£ 30$ of weekly material investments to matter more than moving a child to a better school. Parents perceive the returns to time and material investments to be diminishing and perceive material investments as more productive if children attend higher quality schools. Perceived returns do not differ with the child's initial human capital or gender and, surprisingly, we find no differences in perceived returns by the parents' socioeconomic background. Consistent with parental beliefs playing an important role in parental investment decisions, perceived returns are found to be highly correlated with actual investment decisions.

Orazio Attanasio

Department of Economics University

College London

Gower Street

London WC1E 6BT

United Kingdom

and NBER

o.attanasio@ucl.ac.uk

Teodora Boneva

University of Oxford

10 Manor Road

OX1 3UQ Oxford

United Kingdom

teodora.boneva@economics.ox.ac.uk

Christopher Rauh

Département de sciences économiques

Université de Montréal

C.P.6128, succ. Centre-Ville

Montréal, QC

Canada H3C 3J7

christopher.raphael.rauh@umontreal.ca
\end{abstract}




\section{Introduction}

There are many ways in which parents can provide a stimulating educational environment for their children. Parents can devote attention to their children by spending time with them. They can also invest money by, for instance, purchasing educational games/toys or hiring a private tutor. Moreover, parents can choose to send their children to private schools or can move to a better neighborhood where schools are of higher quality. While it has been well documented that these parental investments are highly predictive of important life outcomes such as educational attainment, earnings and health, it has also been established that the time and financial resources, which parents allocate towards their children, varies considerably across different families (e.g. Cooksey and Fondell 1996; Guryan, Hurst and Kearney 2008; Lareau 2011; Attanasio et al. 2013; Carneiro, Meghir and Parey 2013; Putnam 2015). This raises the question of what drives those differences in parental investment decisions.

To understand why some parents invest more into their children than others, it is imperative to understand how parents think about the returns to investments. While differences in available resources might explain some of the variation in investments, parental beliefs about the returns to investments are likely to play a crucial role in parents' educational investment decisions. In order to get to the source of differential investments, it is therefore essential to shed more light on how parents differ in their beliefs about the returns to different types of investments and how their beliefs are related to actual investment choices. While estimating the actual returns to different investments is important for understanding which parental investments matter, shedding more light on how parents perceive the returns to investments is crucial for our understanding of how parental investments respond to policy changes. With this aim in mind, we collect and describe a novel representative dataset on parental beliefs about the productivity and usefulness of their investments.

We make several contributions to the literature. First, we document how parents perceive the returns to different types of educational investments made in school children (i.e. time investments, material investments and school quality) using a large nationally representative sample of parents with school-age children. Second, given that the returns to different activities might not be independent, we investigate how parents perceive the complementarity/substitutability between the different types of investments. In analyzing our data, we pay particular attention to studying the extent to which beliefs

about returns are heterogeneous in different dimensions. Finally, we investigate whether differences in perceived returns are predictive of actual investment decisions made by parents.

Observed educational choices are consistent with many different alternative specifications of preferences 
and beliefs, which is why it is not possible to investigate the role of beliefs in educational investment decisions using choice data alone (Manski 2004). For this reason, we conduct a novel representative survey and elicit parental beliefs directly using hypothetical investment scenarios. The approach we use is related to the elicitation of information on subjective expectations about certain events. When applied to future earnings this approach was pioneered by Dominitz and Manski (1996) and it has been successfully used in a growing number of studies (e.g. Jensen 2010; Attanasio and Kaufmann 2014; Kaufmann 2014). ${ }^{1}$ In a recent study, Cunha, Elo and Culhane (2013) make an important contribution to the literature by developing a methodology for eliciting parental beliefs about the returns to parental investments using hypothetical scenarios. In a sample of parents with low socioeconomic status, they document beliefs about the returns to parental investments made in children aged 0-2. In this paper, we build on Cunha, Elo and Culhane (2013) and investigate how parents perceive the returns to different types of parental investments made in school children. By constructing hypothetical scenarios we can vary one educational input at a time while keeping other factors constant, which allows us to elicit individual perceived returns to different types of investments as well as their interactions.

To elicit parental beliefs about the properties of the process of skill formation and to collect information on parents' actual investment decisions, we administer a survey to a representative sample of 1,962 parents living in England. To the best of our knowledge, we are the first to elicit parental beliefs about the returns to parental investments in a nationally representative sample. To be eligible to participate in the study, parents had to have at least one child aged 5-16 years living with them in their home. The sample was selected to be representative of the English population of interest in terms of region, gender and education level of the responding parent, as well as the age and gender of the respondent's child. To elicit parental beliefs about the productivity of different types of investments made in school children, we present all parents with hypothetical investment scenarios which vary along three dimensions: (i) the level of parental time investments, (ii) the level of parental material investments, and (iii) the quality of the school the child currently attends. For each scenario, parents are asked to state what the future earnings of the child will be at age 30 . This research design allows us to investigate how parents perceive the returns to these three different inputs and it allows us to examine whether parents perceive the different inputs as substitutes or complements. Mapping the scenarios considered into expected returns hence allows us to characterize parental perceptions of the process of skill formation and of the role played by different inputs. By asking about hypothetical

\footnotetext{
${ }^{1}$ See Manski (2004) for a review and discussion of different survey elicitation approaches.
} 
families rather than the respondents' own family we can vary inputs across scenarios and abstract from individual (unobserved) differences across respondents. In addition, we also investigate whether perceived returns are diminishing, and whether the perceived returns differ with the characteristics of the child. For this purpose, we randomize parents into different groups that vary along four different dimensions: (i) the initial level of time and money invested, (ii) the initial skill level of the child in the scenario, (iii) the gender of the child, and (iv) the age at which the educational investments are made.

Some clear results emerge from our study. While parents think that school quality matters, they also think that parental home inputs play a very important role. In fact, they believe that an additional 3 hours per week in terms of time investments or an additional $£ 30$ per week in terms of material investments matter more than moving a child from a school which 'Requires Improvement' to a school that is 'Outstanding'. The average perceived return to this change in school quality is $10 \%$ in terms of earnings at age 30 , while the average perceived return to 3 additional hours of weekly time investments is $21 \%$, and the average perceived return to $£ 30$ additional weekly material investments is $15 \%$. All these perceived average returns are significantly different from each other. Moreover, we find that there is a perceived complementarity between home and school inputs, i.e. parents perceive the returns to material resources at home to be higher if the children also attend better schools. We further document that parents perceive the productivity of time and material inputs to be diminishing, i.e. the returns per hour $/ £$ invested decrease with an additional hour $/ £$ invested. We find no significant differences in perceived returns to school, time or material investments by the initial skill level or the gender of the child in the scenario. This suggests that parents believe that children of low and high ability, as well as boys and girls respond similarly to each type of investment. We further document that parents believe that the returns to school quality are higher for older children.

Turning to the question how perceived returns vary across respondents, we document a substantial amount of heterogeneity in perceived returns. We find that perceived returns to the different types of investments correlate strongly. Those parents who perceive the returns to school quality to be high are also more likely to perceive high returns to parental time and material investments. Perhaps surprisingly, we do not find detectable systematic differences in perceived returns by socioeconomic background or income variables in this nationally representative sample of parents. This evidence contrasts with some of the discussions in the literature, for instance with the hypotheses proposed by Lareau (2011) or with the findings in Boneva and Rauh (2018).

Importantly, we find that perceived returns are correlated with actual reported investment decisions. 
Parents who perceive the returns to time investments to be higher spend more time interacting with their children, parents who perceive the returns to material investments to be higher spend more money on learning resources, and parents who perceive the returns to school quality to be higher spend significantly more money on school fees. While we do not provide direct evidence for a causal link between beliefs and investments, our descriptive results are consistent with parental beliefs playing an important role in parental investment decisions.

Given that parental beliefs to the different types of investments correlate strongly, a natural question which arises is why some parents perceive all types of investments as very important while other parents do not. While we are not be able to provide an ultimate answer to the question of how beliefs about returns are formed, we note that one underlying reason for why some parents may perceive all returns as higher is that those parents believe that children's skills are more malleable in general and more responsive to any type of input. Using a supplementary parental mindset questionnaire, which builds on the work by Dweck (2006), we find evidence that is consistent with this interpretation. These results are important as previous studies have shown that individual investments are responsive to interventions which alter individual beliefs regarding the malleability of skills (see, e.g., Alan, Boneva and Ertac 2015).

Our study relates to several different strands of the literature. First, it relates to the literature on investments made by parents in their children which was pioneered by Becker and Tomes $(1979,1986)$. While traditionally this literature has assumed that parents are endowed with perfect information regarding the production function, recent studies have relaxed this assumption and have drawn attention to the role of parental beliefs. For example, Kinsler and Pavan (2016) and Dizon-Ross (2018) investigate how parental beliefs evolve and how parents tailor educational investments according to their (inaccurate) beliefs about their children's ability, while Caucutt, Lochner and Park (2017) provide a theoretical framework in which they explore how information-based frictions can lead to inefficiently low investments. In contrast to these studies, we do not consider parental beliefs about their children's ability but about the returns to parental investments. Our study most closely relates to Cunha, Elo and Culhane (2013) and Cunha (2014) who use hypothetical scenarios to elicit maternal beliefs about the productivity of investments made in children aged 0-2. To the best of our knowledge, we are the first to document parental beliefs about the returns to different types of educational investments made in school children and to show that these beliefs are significantly related to actual investment choices. 
The present study complements recent work by Boneva and Rauh (2018). ${ }^{2}$ There are several important differences between this study and Boneva and Rauh (2018). First, the present study uses data from a representative sample of parents in England. To the best of our knowledge, this is the first attempt to measure parental beliefs in a large representative sample of the population. Second, and more importantly, Boneva and Rauh (2018) only focus on the perceived returns to parental time investments while this study investigates how parents perceive the returns to three different types of investments made by parents, namely parental time and material investments as well as school quality. This allows us to investigate how parents perceive the complementarity/substitutability between different inputs. To gain a better understanding of how parents react to policy changes (e.g. an increase school quality), it is important for us to know how parents perceive the interaction between different inputs.

Second, our study relates to the literature which examines the importance of individual beliefs about returns to educational investment decisions made by students (e.g., Dominitz and Manski 1996, Jensen 2010, Abramitzky and Lavy 2014, Attanasio and Kaufmann 2014, Kaufmann 2014, Almas et al. 2016, Attanasio and Kaufmann 2017, Boneva and Rauh 2017, Belfield et al. forthcoming). It is also related to how students' beliefs about returns are related to students' choice of major (Montmarquette, Cannings and Mahseredjian 2002; Arcidiacono 2004; Arcidiacono, Hotz and Kang 2012; Beffy, Fougere and Maurel 2012; Zafar 2013; Arcidiacono et al. 2014; Stinebrickner and Stinebrickner 2014; Wiswall and Zafar 2015a,b; Hastings et al. 2016; Wiswall and Zafar 2017; Baker et al. 2017), high-school track (Giustinelli 2016), and which specific university to attend (Delavande and Zafar 2014). Relative to these studies we focus on the beliefs of parents and how these beliefs are related to the educational choices they make for their children.

The rest of the paper is organised as follows: Section 2 presents a stylized model of the production technology that highlights the importance of parental beliefs in parents' educational investment decisions and motivates our survey design. Section 3 presents the survey design that we use to elicit parental beliefs about the characteristics of the production technology, and provides details on the characteristics of the sample. Section 4 presents the results, while Section 5 concludes.

\footnotetext{
${ }^{2}$ It is also related to recent work by Biroli et al. (2018) who investigate parental beliefs about returns to health investments as well as to Lergetporer, Werner and Woessmann (2018) who examine beliefs about the returns to university education in a representative sample of adults in Germany.
} 


\section{Theoretical Framework}

In this section, we present a stylized model to highlight how parental beliefs about the process of development and the returns to investment are likely to be critical for parents' investment decisions. More specifically, we present a simple conceptual framework that describes parents' investment decisions as a result of an optimization problem. In our framework, parents care about the development of their child as well as their own consumption and leisure, and they face a time and a budget constraint as well as a perceived production technology that maps educational investments made by parents into future child outcomes. The technology of skill formation is based on the general skill accumulation framework developed in Cunha, Heckman and Schennach (2010). ${ }^{3}$ However, rather than assuming that the parents know the actual process of skill formation, we assume that they have some beliefs about it, which might be different from the actual process.

We assume that parents care about their own consumption $C_{i}$, the use of their time, and their children's adult outcomes $y_{i}$, such as their earnings and, more generally, well-being. The parents of child $i$ can allocate their total available time $T$ to activities that help child $i$ accumulate skills, $I_{i}^{T}$, leisure activities that do not directly promote the child's human capital, which we henceforth refer to as 'own' leisure time, $L_{i}^{o}$, as well as work, $L_{i}^{w}$. Let the hourly wage be denoted as $w_{i}$. Parents can spend their total income, $w_{i} L_{i}^{w}$, on own consumption, $C_{i}$, monetary investments that help their children acquire skills, $I_{i}^{M}$, as well as expenses related to the quality of the school their child attends, $I_{i}^{S}$. While there are many schools in the UK that do not charge school fees, we can think of school expenditures in this context as any additional expenses the parents have to incur for their child to attend a better school (e.g. higher rents in neighborhoods with good schools). We also assume that parents might enjoy (or not) spending 'investment' time with their children.

We assume that parents perceive child outcomes to depend on the child's characteristics $Z_{i}$, such as the child's stock of skills at the beginning of the period considered or the child's gender, and on three types of investment: time investment, $I_{i}^{T}$, material investment, $I_{i}^{M}$, and the quality of the school the child attends, $I_{i}^{S}$, according to the function $f$ as in

$$
y_{i}=f\left(Z_{i}, I_{i}^{T}, I_{i}^{M}, I_{i}^{S}, \epsilon_{i}\right)
$$

where $\epsilon_{i}$ denotes some random shocks.

\footnotetext{
${ }^{3}$ For the purpose of our analysis, we simplify the framework presented in Cunha, Heckman and Schennach (2010) in several ways, e.g. we do not distinguish between cognitive and non-cognitive skills.
} 
$f$ is assumed to be monotonically increasing, twice continuously differentiable and concave in $I_{i}^{T}$, $I_{i}^{M}$ and $I_{i}^{S}$. We stress that the function $f$, which represents one of the relevant constraints parents face in choosing how to allocate time and financial resources, does not necessarily coincide with the true production function of skills. Parents might have beliefs about the production process that might be distorted. The process of skill formation is complex, it may well be that parents do not have complete or accurate information about how the different inputs map into child outcomes.

We also note that unlike other studies, which elicit the returns to investments on skills (e.g. Cunha, Elo and Culhane 2013) or the returns to skills on the labor market (e.g. Jensen 2010, Attanasio and Kaufmann 2014, Kaufmann 2014) we directly elicit parental beliefs about the returns to investments on labor market outcomes. These beliefs will be a combination of parental beliefs about the process that produces skills but also their beliefs about the returns to these skills on the labor market. We assume that parents care about children's outcomes, rather than children's skills, which is why we directly elicit the returns to investments on future outcomes.

In addition to the constraint that describes the perceived process that generates child outcomes in equation (1), parents face a time constraint:

$$
I_{i}^{T}+L_{i}^{o}+L_{i}^{w}=T
$$

and a budget constraint:

$$
C_{i}+p_{M} I_{i}^{M}+p_{S} I_{i}^{S}=w_{i} L_{i}^{W}
$$

where the price of own consumption is normalized to 1 and $p_{M}$ and $p_{S}$ are the relative prices of monetary investments and school quality respectively, and where we are neglecting savings for expositional simplicity.

If one considers the optimization problem faced by parents, which involves a utility function that depends on $y_{i}, C_{i}$ and possibly $I_{i}^{T}$ and the three constraints in equations (1), (2) and (3), it is clear that parents' investment decisions will depend on: (i) how much they care about their children; (ii) their financial and time resources; and (iii) their perceptions about the process that generates children's outcomes. In particular, from the parents' optimization problem it is apparent that the perceived partial derivatives of the production technology are critical for parents' investment decisions:

$$
\frac{\partial f(\cdot)}{\partial I_{i}^{T}}, \frac{\partial f(\cdot)}{\partial I_{i}^{M}}, \frac{\partial f(\cdot)}{\partial I_{i}^{S}} .
$$


Moreover, we also note that the perceived marginal returns to any given input may depend on the level of the other inputs. For example, it may well be that time investments are perceived as more or less productive if they are complemented with high monetary investments. It is therefore crucial to also investigate how parents perceive the complementarity/substitutability between the different inputs:

$$
\frac{\partial f(\cdot)}{\partial I_{i}^{T} \partial I_{i}^{M}} \lesseqgtr 0 \quad \frac{\partial f(\cdot)}{\partial I_{i}^{T} \partial I_{i}^{S}} \lesseqgtr 0 \quad \frac{\partial f(\cdot)}{\partial I_{i}^{M} \partial I_{i}^{S}} \lesseqgtr 0
$$

In addition, it is also of interest whether parents perceive the returns to the different types of investments to differ with the baseline characteristics of the child, e.g. it may be that parents perceive the returns to differ with the initial human capital of the child.

The features of the true process of skill formation can be estimated from actual data (subject to a number of identification problems that arise from the possible endogeneity of investment choices, see the discussion in Attanasio et al. 2015 and Attanasio, Meghir and Nix 2015). However, investment decisions might not be informed by the features of such processes but by individual perceptions. Without additional information such as the one we elicit, it is not possible to identify the role of parental beliefs from information on parental investments, as beliefs cannot be separated from other factors, such as taste. ${ }^{4}$

While the literature has recognized the importance of parental beliefs in parental investment decisions, not much is known about how parents perceive the returns to different types of investments and how they perceive the complementarity/substitutability between different inputs. We use a novel survey design to elicit these beliefs, which allows us to gain deeper insights into how parents perceive the technology which maps educational inputs into future child outcomes.

\section{Eliciting Parental Beliefs}

To elicit parental beliefs about the properties of the production technology and to collect information on parents' actual investment decisions, we administer a survey to a representative sample of almost 2,000 parents living in England. As motivated by the theoretical framework, parental beliefs about several partial and cross derivatives of the production technology are likely to be critical for the level and composition of educational investments made by parents. We build on Cunha, Elo and Culhane (2013) and use hypothetical investment scenarios to elicit parental beliefs about the characteristics of

\footnotetext{
${ }^{4}$ Attanasio, Cunha and Jervis (2016) show how to identify parental taste within a structural model using information on investment and subjective beliefs.
} 
the production technology. ${ }^{5}$ By constructing hypothetical scenarios we can vary one input at a time while keeping other factors constant, which allows us to elicit individual perceived returns to different educational inputs.

Hypothetical Scenarios: We present all parents with eight different hypothetical scenarios that vary along three key dimensions: (i) the level of parental time investments, $I^{T}$, (ii) the level of parental material investments, $I^{M}$, and (iii) the quality of the school the child attends, $I^{S}$. For each of these eight scenarios, we ask parents to state what they believe the earnings of the child in the scenario will be at age 30. By comparing parents' responses across the different scenarios, we can infer parents' beliefs about the returns to the different types of investments, as well as parental beliefs about the complementarity/substitutability of the different inputs. Our questions allow us to get an estimate of individual expected returns. ${ }^{6}$

More specifically, we ask parents to imagine two hypothetical average British families (the "Jones" and the "Smiths"). In both hypothetical families, there is one child who is currently in school. Parents are told that while the Jones and the Smiths live in the same neighbourhood and are identical in many different respects (e.g., in terms of parental income and education, as well as the intellectual ability of the child), there is one difference between the two families. In particular, they are told that the child of the Jones attends a high quality school that has been rated as 'Outstanding', while the child of the Smiths attends a low quality school that has been rated as 'Requires Improvement'. ${ }^{7}$ We deliberately made it explicit that the two hypothetical families are otherwise identical, as this allows us to abstract from other potential differences between the families. Different respondents might have different beliefs about the returns to parental investment, an important dimension of heterogeneity which is at the center of this study.

For each of these two hypothetical families, parents are then presented with four different investment scenarios that vary in the levels of parental time investments, $I^{T}$, and the level of parental material investments, $I^{M}$. Put together, the four different investment scenarios are (1) low time investments/low material investments, (2) low time investments/high material investments, (3) high time investments/low

\footnotetext{
${ }^{5}$ Cunha, Elo and Culhane (2013) do not elicit parental beliefs about the returns to different types of investments. Another important difference between the two studies is that while we elicit parental beliefs about how parental investments made during a child's school life map into later-life outcomes, Cunha, Elo and Culhane (2013) elicit parental beliefs about how parental investments in very early childhood (i.e. age 0-2) map into increased skill levels at age 2.

${ }^{6}$ Given that we did not want to burden respondents with a very long questionnaire, we did not elicit information about individual uncertainty about human capital investment returns.

${ }^{7}$ In England, schools are regularly inspected by Ofsted, a non-ministerial department of the UK government. A school can obtain one of the following ratings: 'Outstanding', 'Good', 'Satisfactory/Requires Improvement', 'Inadequate'. In 2017, 21\% of all schools in England are rated as 'Outstanding', $68 \%$ as 'Good', 9\% as 'Requires improvement', and 2\% as 'Inadequate'.
} 
material investments, and (4) high time investments/high material investments. Parents saw all four scenarios for each hypothetical family simultaneously on one screen, i.e. they could compare across the four scenarios while responding to the questions. The order of the four scenarios on the screen was randomized across respondents. We highlighted the differences across scenarios by underlining the aspects we varied (see Appendix B). In total, each parent is thus presented with eight different scenarios, which are illustrated in Table 1. For each of these eight scenarios $j$, parents are asked to state what they expect the earnings of the hypothetical child to be at age $30\left(\tilde{y}_{j}\right)$. We ask parents about the likely future earnings of the child, instead of asking about some interim test result, because this allows us to calculate expected returns without having to rely on assumptions about the returns of arbitrarily scaled test scores.

Interpreting this approach through the lenses of a production function that relates different inputs to outcomes, we see that the way our questions are constructed map eight different points of a threedimension space (time, material and school quality) into possible outcomes. We can therefore estimates the returns to specific investments over the variations considered by the different scenarios. We cannot measure individual beliefs about the returns to investments outside the scenarios considered without some arbitrary extrapolation.

By asking quantitative questions we avoid the pitfalls of interpreting value judgements such as "very important" on a Likert scale. While the questions were not straightforward to answer, we note that randomness in responses would increase measurement error, and therefore would make it less likely for us to find significant returns and meaningful differences across scenarios, as well as significant correlations between beliefs and actual investments. We are aware of the presence of measurement error, which inspires us to reduce the problem by taking the average, when meaningful, of different measures. We purposely also did not provide any information about average earnings in order not to prime respondents. ${ }^{8}$

We can use the parents' responses to the eight different scenarios to infer how parents perceive the returns to the three different educational inputs (i.e. the partial derivatives in (4)) by comparing parents' responses in scenarios in which a specific educational investment is low to the corresponding scenario in which the educational investment is high. In addition, the survey design allows us to document how parents perceive the complementarity/substitutability between the different inputs (i.e. the cross derivatives in (5)). For example, by comparing the perceived return to time investments

\footnotetext{
${ }^{8}$ A similar methodology has also been successfully used in Boneva and Rauh (2018) who focus exclusively on beliefs about the returns to time investments.
} 
when school quality is high to the perceived return to time investments when school quality is low, we can learn something about the perceived complementarity/substitutability between parental time investments and school quality.

Table 1: Overview of the Eight Different Scenarios $(2 \times 2 \times 2)$

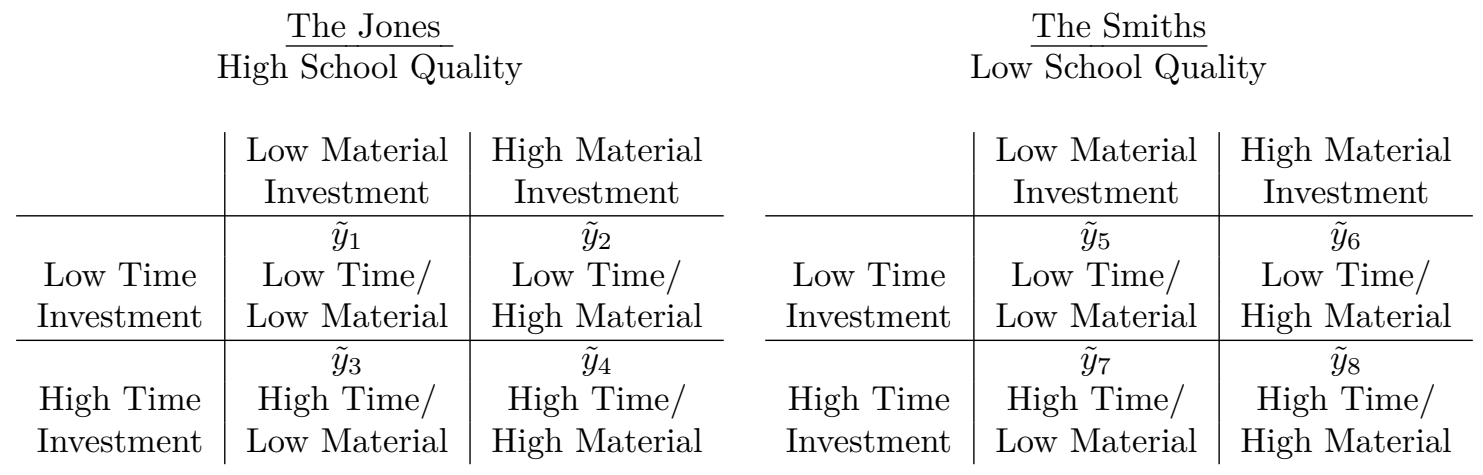

While each parent is presented with these eight different scenarios, we additionally randomize parents into different groups that vary along four different dimensions: (i) the initial level of time and money invested, (ii) the initial skill level of the child in the scenario, (iii) the gender of the child, and (iv) the age at which investments are made. We describe each of these four randomizations in turn and summarize the key facts in Table 2 .

Randomization 1 - Initial Level: While all parents see the eight scenarios presented in Table 1, we vary the amount of time and money which is associated with low and high levels of time and material investments between parents. Respondents are randomized into two different groups. For the first group ('Group 0'), a low (high) level of time investment refers to spending 0 hours (3 hours) every week helping the child acquire new skills, while a low (high) level of material investment refers to spending $£ 0$ (£30) every week on educational resources which help the child acquire new skills. For the second group ('Group 1'), a low (high) level of time investment refers to spending 1 hour (4 hours) every week helping the child acquire new skills, while a low (high) level of material investment refers to spending $£ 10$ ( $£ 40)$ every week on educational resources which help the child acquire new skills. This research design allows us to investigate whether parents perceive the returns to parental time and material investments to be diminishing. 
Table 2: Overview of the Sixteen Different Groups $(2 \times 2 \times 2 \times 2)$

\begin{tabular}{|c|c|}
\hline \multicolumn{2}{|c|}{ Randomization 1: Initial Level } \\
\hline $\begin{array}{l}\text { Low levels of investments: } 0 \mathrm{~h} \text { and } £ 0 \\
\text { High levels of investments: } 3 \mathrm{~h} \text { and } £ 30\end{array}$ & $\begin{array}{l}\text { Low levels of investments: } 1 \mathrm{~h} \text { and } £ 10 \\
\text { High levels of investments: } 4 \mathrm{~h} \text { and } £ 40\end{array}$ \\
\hline \multicolumn{2}{|c|}{ Randomization 2: Initial Skill } \\
\hline $\begin{array}{c}\stackrel{\text { Low }}{\text { Initial skills are low }} \text { ('did not achieve expected level’) }\end{array}$ & $\begin{array}{c}\frac{\text { High }}{\text { Initial skills are high }} \\
\text { ('achieved expected level') }\end{array}$ \\
\hline \multicolumn{2}{|c|}{ Randomization 3: Gender } \\
\hline $\begin{array}{l}\text { Children in scenarios are female } \\
\text { ('Jane' and 'Sarah') }\end{array}$ & $\begin{array}{l}\text { Children in scenarios are male } \\
\text { ('John' and 'Simon') }\end{array}$ \\
\hline \multicolumn{2}{|c|}{ Randomization 4: Age } \\
\hline $\begin{array}{l}\text { Years 3-6 } \\
\text { Child in scenario is in Year } 3 \\
\text { Investments made in Years } 3-6\end{array}$ & $\begin{array}{l}\text { Years } 7-10 \\
\text { Child in scenario is in Year } 7 \\
\text { Investments made in Years } 7-10\end{array}$ \\
\hline
\end{tabular}

Randomization 2 - Initial Skill: To investigate whether parental beliefs differ with the initial skill level of the child, we also randomize the skill levels of the two children in the hypothetical families across respondents. One group of parents is presented with two children whose initial skills are low, while the other group of parents is presented with two children whose initial skills are high. More specifically, the children with low initial skill levels are described as not having achieved the expected level on the most recent key stage examination, which is a national standardized test all children in England need to take, while children with high initial skill levels are described as having achieved the expected level. If the parent is presented with a child in Year 3 then the key stage examination which is being referred to is the Key Stage 1 examination, which is taken in Year 2. If the parent is presented with a child in Year 7 then the key stage examination which is being referred to in the scenario is the Key Stage 2 examination, which is taken in Year $6 .^{9}$

Randomization 3 - Gender: To investigate whether parental beliefs about the characteristics of the production function differ by the gender of the child, we randomize the gender of the hypothetical

\footnotetext{
${ }^{9}$ In 2016, the percentage of students in England achieving the expected levels in the Key Stage 1 examination is $74 \%$, $65 \%$ and $73 \%$ in reading, writing and mathematics, respectively. The percentage of students achieving the expected levels in the Key Stage 2 examination is $66 \%, 74 \%, 73 \%$ and $70 \%$ in reading, writing, grammar/spelling/punctuation, and mathematics, respectively.
} 
child in the scenario across parents. While one group of parents is presented with scenarios in which the children are boys ('John' and 'Simon'), the other group is presented with scenarios in which the children are girls ('Jane' and 'Sarah'). Not only does this design allow us to establish whether parents perceive the potential earnings of girls to be different from those of boys, but we can also investigate whether parents perceive the productivity of investments to differ by gender.

Randomization 4 - Age: Finally, we randomize the age at which investments are made across respondents. While one group is presented with scenarios in which the hypothetical children are in Year 3 of primary school, the other group is presented with scenarios in which the hypothetical children are in Year 7 of secondary school. The school years during which investments are made for the first group of respondents are school years 3-6, while the school years during which investments are made for the second group are school years 7-10.

\subsection{Summary Statistics}

All data was collected by a professional survey company in Oct-Nov 2016. All participating parents were part of the company's online panel and participated in the survey online. Parents received modest incentives for completing the survey in the form of points that they could collect and later exchange for small gifts. To be eligible to participate in the survey, parents had to have at least one child aged 5-16 years living with them in their home. If the parent had more than one child, they were asked about one randomly selected child (henceforth referred to as the 'target' child). The sample was selected to be representative in terms of region in England, the gender and education level of the responding parent, as well as the age and gender of the respondent's child. The survey company used quota-based sampling when contacting parents to participate. To correct for any imbalances in response rates, we re-weight the sample using survey weights when performing the analyses.

The sample consists of 1,962 parents who completed the survey and the characteristics are reported in Table $3{ }^{10}$ In terms of parental characteristics, $50 \%$ of the parents in the sample are male with the average parent being 42 years old. Parents have on average 1.5 children in their household. $58 \%$ and $17 \%$ work full-time and part-time respectively, and $13 \%$ of respondents are single parents. $45 \%$ of responding parents have a university degree, and in $55 \%$ of cases, at least one of the child's parents has a degree. The mean annual household income is $£ 44,890$.

\footnotetext{
${ }^{10}$ We drop observations where the target child is home-schooled or boards at a school. This removed 55 observations. Participating parents could skip questions they did not wish to answer which resulted in some missing values for some of the collected variables.
} 
We use data from the Family Resources Survey (FRS) 2013-2014 to compare our sample statistics to the statistics of a representative sample of parents with 5-16 year old children in England. The average annual household income in the representative sample is $£ 44,296$, which is very similar to the average household income of $£ 44,890$ we report in our sample. Figure C.1 in the Appendix depicts the distribution of household incomes both in our sample as well as in the Family Resources Survey. We also find similar employment statistics in both samples. In the FRS, $53 \%$ of parents work full-time, while $21 \%$ work part-time. In terms of education, we find that the parents in our sample are somewhat better educated than the parents in the FRS. More specifically, we find that in the FRS $31 \%$ of parents have a university degree, while $42 \%$ of households have at least one parent with a university degree. To make our sample comparable to the nationally representative sample, we use inverse probability weights in the analysis in order to re-weigh the observations to account for the differences in education levels. We note that our results are not materially affected by the use of these survey weights.

In terms of characteristics of the target child, for whom the parents completed the survey, $50 \%$ are male, and the average child is 10 years old and in Year 6 at school. Table A.1 shows the distribution of Ofsted ratings for the school of the selected child. $85 \%$ of children in the sample attend either a Good or an Outstanding school. Ofsted data for the 2016-17 academic year shows that $89 \%$ of all schools in England are rated as either Good or Outstanding. Sample characteristics are well balanced over the sixteen groups into which respondents were randomly allocated.

Table 3: Summary statistics

\begin{tabular}{|c|c|c|c|}
\hline Variable & Mean & Std. Dev. & $\overline{\mathrm{N}}$ \\
\hline Male parent & 0.504 & 0.500 & 1962 \\
\hline Age of parent & 42.043 & 8.165 & 1962 \\
\hline Other parent in household & 0.873 & 0.333 & 1962 \\
\hline Foreign language at home & 0.197 & 0.398 & 1962 \\
\hline Parent works full-time & 0.578 & 0.494 & 1962 \\
\hline Parent works part-time & 0.174 & 0.379 & 1962 \\
\hline Parent has degree & 0.454 & 0.498 & 1957 \\
\hline Household income & 44889 & 24456 & 1836 \\
\hline At least one parent has degree & 0.546 & 0.498 & 1962 \\
\hline Number of children & 1.543 & 0.700 & 1962 \\
\hline Own child goes to private school & 0.045 & 0.207 & 1945 \\
\hline Own child is male & 0.504 & 0.500 & 1962 \\
\hline Own child's school year & 6.223 & 3.535 & 1962 \\
\hline Age of own child & 10.412 & 3.464 & 1962 \\
\hline
\end{tabular}

Parental Investments: In order to determine whether parental beliefs about the returns to 
investments can be used to predict actual investments in their own children, we also ask parents about the investments they currently make in their child. Tables A.2 and A.3 in the Appendix provide summary statistics for the responses to the own investment questions. Parents are asked about both time and material investments. For time investments, we ask how much time they spend on weekdays and weekends on activities with their child such as reading, conversing, playing and helping with school work. For material investments, respondents are asked to report their average monthly spending on various educational categories, namely books, educational games/toys, societies, private tuition and school fees.

As shown in Table A.2, parents spend on average more time per day with their children during the weekend than on weekdays. In both cases, conversing with their child is the most time-consuming activity with the average parent spending almost 80 minutes and close to two hours per day talking with their child during weekdays and weekends respectively. Across all activities, parents spend on average almost 25 hours per week with their children. Table A.3 provides summary statistics on material investments. The average parent spends $£ 150$ per month on such investments, of which $£ 110$ are spent on school fees and societies. The order of the different survey blocks was randomized across respondents.

\section{Results}

\subsection{Characterising Subjective Beliefs Data}

To get a better understanding of how parents perceive the properties of the process of skill formation, we estimate an ordinary least squares regression relating child outcomes to different input scenarios, allowing for interactions between different inputs. More specifically, we estimate variants of the following empirical specification:

$$
\log \tilde{y}_{j i}=\alpha+\beta_{1} I_{j}^{T}+\beta_{2} I_{j}^{M}+\beta_{3} I_{j}^{S}+\beta_{4} I_{j}^{T} \times I_{j}^{M}+\beta_{5} I_{j}^{T} \times I_{j}^{S}+\beta_{6} I_{j}^{M} \times I_{j}^{S}+\gamma_{i}+\epsilon_{j i},
$$

where $j$ indicates the scenario, $\tilde{y}_{j i}$ are the earnings parent $i$ expects in scenario $j, \alpha$ is the intercept, $I_{j}^{T}$ is a dummy variable which equals 1 if parental time investments are high (in scenario $j$ ), $I_{j}^{M}$ is a dummy variable which equals 1 if parental material investments are high, $I_{j}^{S}$ is a dummy variable which indicates whether school quality is high, and $\gamma_{i}$ are parent fixed effects. As motivated in Section 2, we are interested in the perceived returns to the different educational inputs. These perceived returns 
will be captured by the estimates of $\beta_{1}, \beta_{2}$ and $\beta_{3}$. In addition, if parents perceive the different inputs as complements (substitutes), we expect the coefficients on the interaction terms (i.e. $\beta_{4}, \beta_{5}$ and $\beta_{6}$ ) to be positive (negative).

As mentioned in the previous section, we additionally randomize respondents into different groups which vary along four different dimensions: (i) the initial level of time and money invested, (ii) the initial skill level, (iii) the gender and (iv) the age of the child. We investigate whether the main results differ along any of these four dimensions by splitting the sample and performing the analyses on the different subgroups. This approach allows us to study features such as the curvature of the process relating inputs to child outcomes and the role of initial conditions and interactions. For instance, equation (6) assumes that increasing investment (in time or material) will have the same effect on child outcomes independently of the starting point. Estimating the equation allowing different coefficients depending on whether the time investment started from 0 or 1 hours (or whether the material investment started from $£ 0$ or $£ 10$ ) relaxes this assumption.

\subsection{Parental Beliefs about the Production Technology}

Figure 1 shows the expected earnings for the eight hypothetical scenarios averaged across all respondents. ${ }^{11}$ Expected earnings are increasing in all three investment types, namely school quality, time and material investments. The average expected earnings for a child who attends a high quality school are $£ 27,543$ for low-time and low-material investments, $£ 32,747$ for low-time and high-material investments, $£ 33,807$ for high-time and low-material investments, and $£ 40,083$ for high-time and high-material investments. When the quality of the school the child in the scenario attends is low, the average expected earnings are $£ 24,974$ for low-time and low-material investments, $£ 29,021$ for low-time and high-material investments, $£ 30,382$ for high-time and low-material investments, and $£ 35,450$ for high-time and high-material investments. The average across these eight scenarios is $£ 31,751$.

There are several patterns worth noting. First, parents seem to give meaningful responses in the sense that higher levels of investments are also associated with higher levels of expected earnings. Second, parents are on average remarkably close in their estimates to the true average. Using the Family Resource Survey of 2013-14, we find the average annual earnings of women and men working at least 30 hours who are $25-34$ years old to be 25,630 and 30,977 , respectively. It is also noteworthy that in both panels, average expected earnings are higher for high-time and low-material investments

\footnotetext{
${ }^{11}$ To ensure that our results are not driven by outliers, we set the responses of those individuals to missing for whom the implied returns to school, time or material investments are in the top or bottom $1 \%$ of the returns distribution.
} 
Figure 1: Expected earnings under hypothetical scenarios

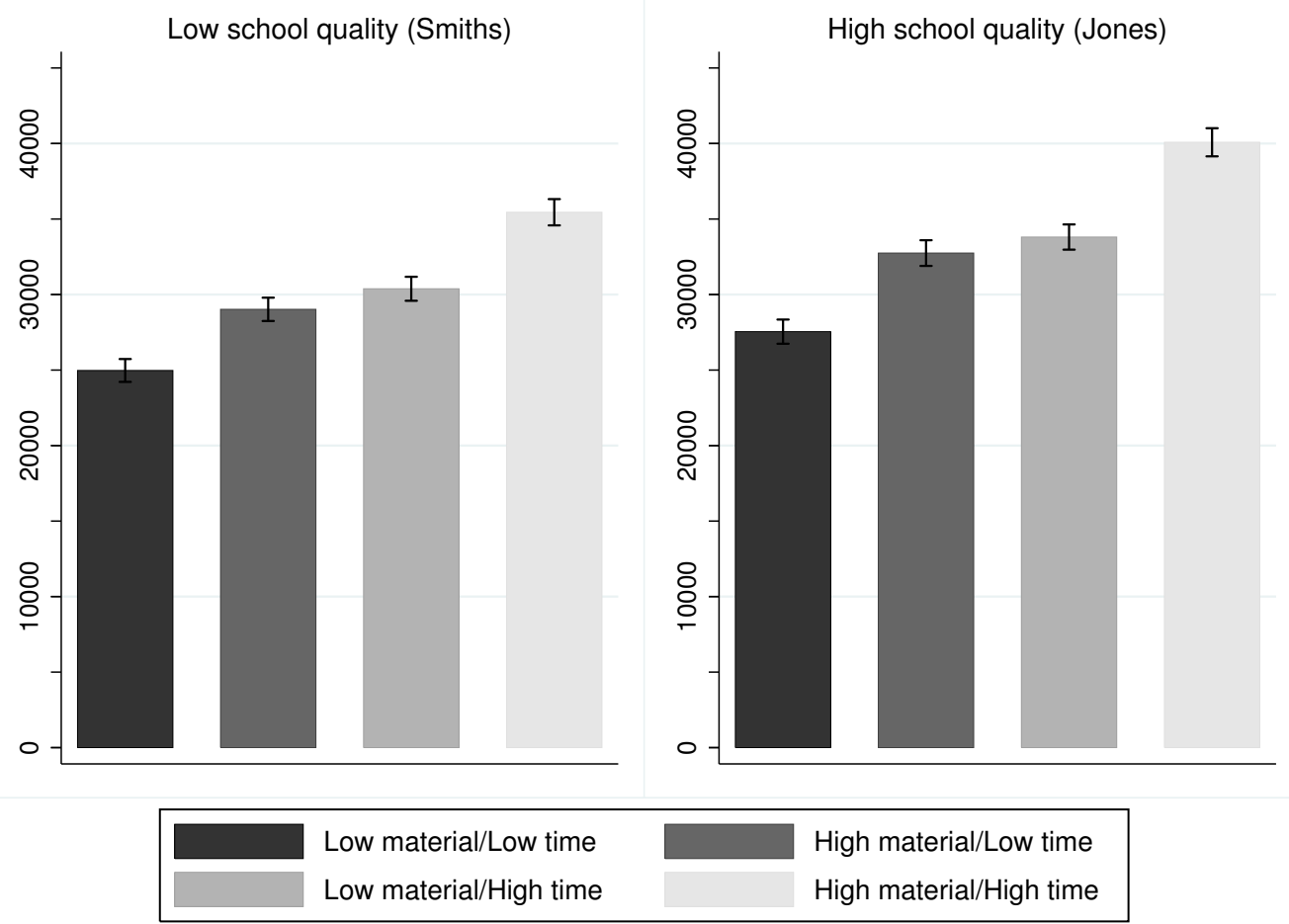

Note: This figure shows expected earnings (in $£ s$ ) of the child at age 30 , averaged across all respondents, for each of the eight hypothetical scenarios with $95 \%$ confidence intervals (see Table 1). The left panel shows the mean expected earnings in the four scenarios with low school quality while the right panel shows the mean expected earnings in the scenarios with high school quality.

(bar 3) relative to low-time and high-material investments (bar 2), thereby suggesting that parents perceive the returns to 3 additional hours of weekly time investments to be higher than the returns to a rise of $£ 30$ in weekly material investments.

Table 4 shows the results from regressing log expected earnings of the child in scenario $j$ as reported by parent $i$ on indicator variables for high school quality $\left(I^{S}\right)$, high levels of time investments $\left(I^{T}\right)$ and high levels of material investments $\left(I^{M}\right)$. In this analysis, we pool all respondents irrespective of which group they were randomized into (see Table 2), so the results average across respondents who have seen different initial levels of investments and children with different skills at baseline, gender and age.

We begin by running the model without respondent fixed effects (Column 1). We then subsequently add in respondent fixed effects (Column 2) and, in order to examine whether there is perceived substitutability/complementarity between investment types, interaction terms between the indicator 
Table 4: Determinants of log perceived earnings at age 30

\begin{tabular}{lccc}
\hline \hline \multicolumn{3}{l}{ Dependent variable: Perceived log earnings at age 30 } \\
\hline High school quality & $0.107^{* * *}$ & $0.107^{* * *}$ & $0.096^{* * *}$ \\
& $(0.006)$ & $(0.005)$ & $(0.008)$ \\
High time investment & $0.203^{* * *}$ & $0.208^{* * *}$ & $0.210^{* * *}$ \\
& $(0.007)$ & $(0.006)$ & $(0.009)$ \\
High material investment & $0.140^{* * *}$ & $0.153^{* * *}$ & $0.151^{* * *}$ \\
& $(0.007)$ & $(0.006)$ & $(0.009)$ \\
School x Time & & & 0.007 \\
& & & $(0.007)$ \\
School x Material & & & $0.014^{*}$ \\
& & & $(0.007)$ \\
Time x Material & & & -0.011 \\
& & & $(0.010)$ \\
Constant & & & $10.014^{* * *}$ \\
& $10.020^{* * *}$ & $10.011^{* * *}$ & $(0.007)$ \\
\hline Sample mean & $(0.014)$ & $(0.006)$ & $£ 32,875$ \\
Respondent fixed effects & $£ 32,875$ & $£ 32,875$ & Yes \\
Observations & No & Yes & 14402 \\
R-squared & 14402 & 14402 & 0.228 \\
\hline \hline
\end{tabular}

Notes: Standard errors in parentheses. $* \mathrm{p}<0.10,{ }^{*} \mathrm{p}<0.05, * * * \mathrm{p}<0.01$ Standard errors are clustered at the parent level. Observations are weighted according to the age and gender of the parent's own child and the education level of the responding parent. Regressions are performed using the responses to all eight hypothetical investment scenarios. The dependent variable is the perceived log earnings of the hypothetical child at age 30. 'High school quality' is a dummy variable equal to 1 if the hypothetical child attends a school with an 'Outstanding' Ofsted rating (i.e. the child is from the Jones family). 'High time investment' and 'High material investment' are dummy variables equal to 1 if the scenario involves the higher level of time and material investments respectively. Columns (1) and (2) give the results from pooled OLS and fixed effects estimation respectively. The final column adds in interaction terms between the three dummy variables corresponding to high levels of the three investment types to the fixed effects model estimated in Column (2). 'Sample mean' refers to the average expected earnings (in $£ s$ ) across all eight scenarios for the 14,402 observations used in the estimation.

variables (Column 3). Our results are robust to these different specifications. The results in Column 3 show that attending a high quality school is associated with a $9.6 \%$ increase in expected earnings. Spending three more hours per week with the child translates to a rise in expected earnings of $21.0 \%$, while spending $£ 30$ more per week translates to a rise in expected earnings of $15.1 \%$. All these estimates are highly significant at the $1 \%$ level. Moreover, the coefficient on time investments is significantly higher than the coefficient on material investments, suggesting, as in Figure 1, that parents perceive 3 hours of additional time investments to be more productive than $£ 30$ of additional material investments (at the $1 \%$ level). Both of these perceived returns are in turn significantly greater than the perceived returns to school quality (at the $1 \%$ level). As shown in column (3), parents do not perceive parental 
time investments to be complementary to school quality or parental material investments. They do, however, perceive the returns to parental material investments to be significantly higher if the child attends a high quality school. In particular, parents perceive the returns to $£ 30$ of weekly material investments to be $9.3 \%$ (or 1.4 percentage points) greater if the child attends a school which is rated as 'Outstanding' rather than a school which 'Requires Improvement'.

Whether parental beliefs on the returns to different types of investment are roughly correct is an interesting question, but one that would be very hard to answer with the data we have available. In observational data, it is difficult to find exogenous variation in educational investments made by parents that would allow us to obtain unbiased estimates of their returns to which we could compare the beliefs data. Having said that, if the data on individual beliefs are accurate, they should be informative about parental investment, regardless of whether beliefs about returns are correct.

Tables 5 and 6 show the results from performing the analysis separately for the different subgroups respondents were randomized in (see overview in Table 2). As in Table 4, expected earnings are significantly increasing in the three investment types for each subgroup. With regards to differences between subgroups, Panel A of Table 5 provides evidence of perceived diminishing returns to parental time and material investments. More specifically, the returns are perceived as significantly higher when investments rise from 0 hours to 3 hours and from $£ 0$ to $£ 30$ ('Group 0 ') than when investments rise from 1 hour to 4 hours and from $£ 10$ to $£ 40$ ('Group 1'). Note also that there is a significant difference in the intercept, as Group 1's baseline level of investment is higher, and no significant difference in expected returns to school quality, as one would expect. Turning to differences across initial skill levels (Panel B of Table 5), parents believe that high ability children will earn more in the future (as indicated by the significantly different intercept). However, they do not perceive the returns to investments to differ depending on the initial level of the child's skill. Similarly, we do not find that parents perceive the returns to be different depending on the gender of the child (Panel A of Table 6). Finally, when we compare the perceived returns to investments by the year of school the child in the scenario is currently in, we find that parents perceive the returns to school quality to be higher when the child in the scenario is in Year 7 rather than in Year 3 (Panel B of Table 6). ${ }^{12}$

We note that for all different subgroups we find a positive coefficient on the interaction term between parental material investments and school quality. However, this coefficient is now less precisely

\footnotetext{
${ }^{12}$ We do not find that parents perceive the returns to parental time or material investments to be different depending on the time period during which investments are made. In contrast, Boneva and Rauh (2018) which uses a withinsubject design to examine the perceived dynamic properties of the production function finds that parents also perceive the returns to parental time investments to be higher in later time periods.
} 
estimated than in Table 4, due to the loss in sample size and is no longer statistically significant at conventional levels.

Table 5: Determinants of log perceived earnings at age $30(2)$

\begin{tabular}{|c|c|c|c|c|c|c|}
\hline & \multicolumn{3}{|c|}{ A: Initial Level } & \multicolumn{3}{|c|}{ B: Initial Skill } \\
\hline & Group 0 & Group 1 & p-value & Low ability & High ability & p-value \\
\hline High school quality & $\begin{array}{c}0.092^{* * *} \\
(0.024)\end{array}$ & $\begin{array}{c}0.109^{* * *} \\
(0.022)\end{array}$ & 0.234 & $\begin{array}{c}0.097^{* * *} \\
(0.024)\end{array}$ & $\begin{array}{c}0.104^{* * *} \\
(0.023)\end{array}$ & 0.596 \\
\hline High time investment & $\begin{array}{c}0.225^{* * *} \\
(0.024)\end{array}$ & $\begin{array}{c}0.186^{* * *} \\
(0.022)\end{array}$ & $0.020^{* *}$ & $\begin{array}{c}0.213^{* * *} \\
(0.024)\end{array}$ & $\begin{array}{c}0.196^{* * *} \\
(0.023)\end{array}$ & 0.305 \\
\hline High material investment & $\begin{array}{c}0.161^{* * *} \\
(0.024)\end{array}$ & $\begin{array}{c}0.124^{\text {*** }} \\
(0.022)\end{array}$ & $0.030^{* *}$ & $\begin{array}{c}0.146^{* * *} \\
(0.024)\end{array}$ & $\begin{array}{c}0.135^{* * *} \\
(0.023)\end{array}$ & 0.547 \\
\hline School x Time & $\begin{array}{c}0.017 \\
(0.028)\end{array}$ & $\begin{array}{c}0.004 \\
(0.025)\end{array}$ & 0.326 & $\begin{array}{c}0.015 \\
(0.027)\end{array}$ & $\begin{array}{c}0.006 \\
(0.026)\end{array}$ & 0.497 \\
\hline School x Material & $\begin{array}{c}0.005 \\
(0.028)\end{array}$ & $\begin{array}{c}0.013 \\
(0.025)\end{array}$ & 0.561 & $\begin{array}{c}0.008 \\
(0.027)\end{array}$ & $\begin{array}{c}0.009 \\
(0.026)\end{array}$ & 0.939 \\
\hline Time x Material & $\begin{array}{l}-0.021 \\
(0.028)\end{array}$ & $\begin{array}{c}0.001 \\
(0.025)\end{array}$ & 0.239 & $\begin{array}{l}-0.008 \\
(0.027)\end{array}$ & $\begin{array}{l}-0.011 \\
(0.026)\end{array}$ & 0.875 \\
\hline Constant & $\begin{array}{c}9.948^{* * *} \\
(0.019)\end{array}$ & $\begin{array}{c}10.098^{* * *} \\
(0.017)\end{array}$ & $0.000^{* * *}$ & $\begin{array}{c}9.989^{* * *} \\
(0.018) \\
\end{array}$ & $\begin{array}{c}10.061^{* * *} \\
(0.018)\end{array}$ & $0.008^{* * *}$ \\
\hline Sample Mean & $£ 31,306$ & $£ 34,407$ & & $£ 32,143$ & $£ 33,590$ & \\
\hline R-Squared & 0.06 & 0.05 & & 0.06 & 0.05 & \\
\hline Observations & 7116 & 7286 & & 7113 & 7289 & \\
\hline
\end{tabular}

Notes: Standard errors in parentheses. $* \mathrm{p}<0.10, * * \mathrm{p}<0.05, * * * \mathrm{p}<0.01$. Standard errors are clustered at the parent level. This table provides disaggregated results based on two group dimensions, namely the initial level of investment (columns 1-3) and the initial skill level (columns 4-6). The third columns provide p-values for testing the equality of individual coefficients between the two subsamples - these are obtained using seemingly unrelated regressions estimation. Regressions are performed using the responses to all eight hypothetical investment scenarios. The dependent variable is the perceived log earnings of the hypothetical child at age 30. 'High school quality' is a dummy variable equal to 1 if the hypothetical child attends a school with an 'Outstanding' Ofsted rating. 'High time investment' and 'High material investment' are dummy variables equal to 1 if the scenario involves the higher level of time and material investments respectively. The remaining three variables are interactions between these three dummy variables. 'Sample mean' refers to the average expected earnings (in $£ s$ ) across all eight scenarios for observations used in each estimation. 
Table 6: Determinants of log perceived earnings at age 30 (3)

\begin{tabular}{|c|c|c|c|c|c|c|}
\hline & \multicolumn{3}{|c|}{ A: Gender } & \multicolumn{3}{|c|}{ B: Age } \\
\hline & Female & Male & p-value & Year 3 & Year 7 & p-value \\
\hline High school quality & $\begin{array}{c}0.112^{* * *} \\
(0.023)\end{array}$ & $\begin{array}{c}0.089^{* * *} \\
(0.024)\end{array}$ & 0.118 & $\begin{array}{c}0.088^{* * *} \\
(0.024)\end{array}$ & $\begin{array}{c}0.114^{* * *} \\
(0.023)\end{array}$ & $0.076^{*}$ \\
\hline High time investment & $\begin{array}{c}0.208^{* * *} \\
(0.023)\end{array}$ & $\begin{array}{c}0.201^{* * *} \\
(0.024)\end{array}$ & 0.654 & $\begin{array}{c}0.217^{* * *} \\
(0.024)\end{array}$ & $\begin{array}{c}0.192^{* * *} \\
(0.023)\end{array}$ & 0.141 \\
\hline High material investment & $\begin{array}{c}0.140^{* * *} \\
(0.022)\end{array}$ & $\begin{array}{c}0.140^{* * *} \\
(0.024)\end{array}$ & 0.991 & $\begin{array}{c}0.147^{* * *} \\
(0.024)\end{array}$ & $\begin{array}{c}0.133^{* * *} \\
(0.023)\end{array}$ & 0.430 \\
\hline School x Time & $\begin{array}{c}0.002 \\
(0.026)\end{array}$ & $\begin{array}{c}0.019 \\
(0.028)\end{array}$ & 0.226 & $\begin{array}{c}0.019 \\
(0.027)\end{array}$ & $\begin{array}{c}0.002 \\
(0.026)\end{array}$ & 0.203 \\
\hline School x Material & $\begin{array}{c}0.009 \\
(0.026)\end{array}$ & $\begin{array}{c}0.008 \\
(0.028)\end{array}$ & 0.941 & $\begin{array}{c}0.015 \\
(0.027)\end{array}$ & $\begin{array}{c}0.003 \\
(0.026)\end{array}$ & 0.377 \\
\hline Time $\mathrm{x}$ Material & $\begin{array}{l}-0.018 \\
(0.026)\end{array}$ & $\begin{array}{l}-0.000 \\
(0.028)\end{array}$ & 0.332 & $\begin{array}{l}-0.027 \\
(0.027)\end{array}$ & $\begin{array}{c}0.008 \\
(0.026)\end{array}$ & $0.068^{*}$ \\
\hline Constant & $\begin{array}{c}10.008^{* * *} \\
(0.017)\end{array}$ & $\begin{array}{c}10.043^{* * *} \\
(0.018)\end{array}$ & 0.200 & $\begin{array}{c}10.022^{* * *} \\
(0.018)\end{array}$ & $\begin{array}{c}10.030^{* * *} \\
(0.018)\end{array}$ & 0.769 \\
\hline Sample Mean & $£ 32,196$ & $£ 33,551$ & & $£ 32,861$ & $£ 32,890$ & \\
\hline R-Squared & 0.06 & 0.05 & & 0.05 & 0.05 & \\
\hline Observations & 7183 & 7219 & & 7175 & 7227 & \\
\hline
\end{tabular}

Notes: Standard errors in parentheses. ${ }^{*} \mathrm{p}<0.10, * * \mathrm{p}<0.05, * * * \mathrm{p}<0.01$. Standard errors are clustered at the parent level. This table provides disaggregated results based on two group dimensions, namely gender (columns 1-3) and the investment period (columns 4-6). The third columns provide p-values for testing the equality of individual coefficients between the two subsamples - these are obtained using seemingly unrelated regressions estimation. Regressions are performed using the responses to all eight hypothetical investment scenarios. The dependent variable is the perceived log earnings of the hypothetical child at age 30. 'High school quality' is a dummy variable equal to 1 if the hypothetical child attends a school with an 'Outstanding' Ofsted rating. 'High time investment' and 'High material investment' are dummy variables equal to 1 if the scenario involves the higher level of time and material investments respectively. The remaining three variables are interactions between these three dummy variables. 'Sample mean' refers to the average expected earnings (in £s) across all eight scenarios for observations used in each estimation.

\subsection{Heterogeneity in Perceived Returns}

The estimates presented in the previous section mask a substantial degree of heterogeneity in perceived returns across respondents. For each respondent, we can calculate the perceived return to time, material and school investments. To obtain a measure of individual perceived returns to time investments, $r_{i}^{\text {Time }}$, we compare the parent's responses in the four scenarios in which time investments are high to the parent's responses in the four corresponding scenarios in which time investments are low. We average across these differences and divide by three to obtain the average perceived return to 1 additional hour of time investments:

$$
r_{i}^{\text {Time }}=\frac{1}{3} \frac{1}{4}\left[\frac{y_{3}-y_{1}}{y_{1}}+\frac{y_{4}-y_{2}}{y_{2}}+\frac{y_{7}-y_{5}}{y_{5}}+\frac{y_{8}-y_{6}}{y_{6}}\right] .
$$


We analogously calculate individual perceived returns to $£ 10$ of material investments, which we denote as $r_{i}^{\text {Material }}$, as well as the perceived returns to high school quality for each respondent, $r_{i}^{\text {School}}$.

Appendix Figure A.1 shows the cumulative distributions of individual perceived returns. The distributions for perceived returns to material and time investments are similar, though perceived returns to time investments are slightly larger indicated through the shift to the right. For school quality, the perceived returns are somewhat more dispersed. Figure A.2 in the Appendix shows the joint distribution of perceived returns to time and material investments (Panel A), time and school investments (Panel B) and material and school investments (Panel C). Again we can see that there is a substantial degree of heterogeneity in perceived returns. Moreover, we can see that parents who perceive one type of investment to be more productive are also more likely to perceive the other types of investments as more productive. This can also be seen in Table 7 which shows the Spearman rank correlations between the different perceived returns. All correlations are positive and significant at the $1 \%$ level. The correlation between the perceived returns to parental time and parental material investments seems to be especially high $(\operatorname{corr}=0.42)$.

Table 7: Spearman rank correlations between perceived returns

\begin{tabular}{llll}
\hline \hline & Time & Material & School \\
\hline Time & 1.000 & & \\
Material & $0.420^{* * *}$ & 1.000 & \\
School & $0.198^{* * *}$ & $0.095^{* * *}$ & 1.000 \\
\hline \hline Note: * $\mathrm{p}<0.10,{ }^{* *} \mathrm{p}<0.05,{ }^{* * *} \mathrm{p}<0.01$. \\
'Time', 'Material' and 'School' refer to the \\
perceived returns to time, material and school \\
quality investments, respectively.
\end{tabular}

While the variation in perceived returns across parents is high, we document in Table 8 that neither parent, nor child or household characteristics can explain a substantial part of the variation in perceived returns. The R-squared of the regressions are low and only few characteristics are associated with parental beliefs about the returns to investments. We document that fathers perceive the returns to school quality as significantly lower compared to mothers, and that older parents as well as parents who are working perceive the returns to time investments as significantly lower. We do not find any significant associations between perceived returns and education of parents or income, irrespective of whether we control for additional household and child characteristics as in Table 8 or not. Parents with a university degree or parents with above median income do not perceive the returns to any of the three types of investments to be greater. To allow for potential non-linearities we also estimate the specification using income quartiles as regressors (see Appendix Table A.4). Again we find no significant 
associations between income and perceived returns. These results are surprising and contrast with the findings in Boneva and Rauh (2018) who document differences in perceived returns to time investments by the socioeconomic background of the respondent. We also do not find any notable differences in perceived returns by the perceived academic ability of the respondent's own child. In the following section, we investigate whether the heterogeneity in perceived returns is associated with actual parental investment decisions.

Table 8: Determinants of perceived returns

\begin{tabular}{|c|c|c|c|c|}
\hline & Time & Material & School & Mindset \\
\hline Male parent & $\begin{array}{c}-0.001 \\
(0.008)\end{array}$ & $\begin{array}{l}-0.001 \\
(0.008)\end{array}$ & $\begin{array}{c}-0.048^{* *} \\
(0.019)\end{array}$ & $\begin{array}{c}-0.183^{* * *} \\
(0.057)\end{array}$ \\
\hline Age of parent & $\begin{array}{c}-0.001^{* *} \\
(0.000)\end{array}$ & $\begin{array}{l}-0.000 \\
(0.000)\end{array}$ & $\begin{array}{c}0.001 \\
(0.001)\end{array}$ & $\begin{array}{c}0.018^{* * *} \\
(0.003)\end{array}$ \\
\hline Number of children & $\begin{array}{l}-0.002 \\
(0.005)\end{array}$ & $\begin{array}{l}-0.000 \\
(0.005)\end{array}$ & $\begin{array}{l}-0.003 \\
(0.013)\end{array}$ & $\begin{array}{c}-0.098^{* * *} \\
(0.033)\end{array}$ \\
\hline Other parent in household & $\begin{array}{c}0.003 \\
(0.011)\end{array}$ & $\begin{array}{l}-0.002 \\
(0.010)\end{array}$ & $\begin{array}{c}0.022 \\
(0.023)\end{array}$ & $\begin{array}{c}0.007 \\
(0.071)\end{array}$ \\
\hline Parent works full-time & $\begin{array}{l}-0.014^{*} \\
(0.008)\end{array}$ & $\begin{array}{l}-0.005 \\
(0.007)\end{array}$ & $\begin{array}{c}0.023 \\
(0.019)\end{array}$ & $\begin{array}{l}-0.058 \\
(0.054)\end{array}$ \\
\hline At least one parent has degree & $\begin{array}{l}-0.002 \\
(0.007)\end{array}$ & $\begin{array}{c}-0.007 \\
(0.007)\end{array}$ & $\begin{array}{c}0.011 \\
(0.017)\end{array}$ & $\begin{array}{c}0.014 \\
(0.051)\end{array}$ \\
\hline Own child goes to private school & $\begin{array}{l}-0.006 \\
(0.015)\end{array}$ & $\begin{array}{c}0.012 \\
(0.017)\end{array}$ & $\begin{array}{c}0.062 \\
(0.045)\end{array}$ & $\begin{array}{c}0.104 \\
(0.126)\end{array}$ \\
\hline High Income & $\begin{array}{c}0.003 \\
(0.008)\end{array}$ & $\begin{array}{l}-0.004 \\
(0.007)\end{array}$ & $\begin{array}{c}0.004 \\
(0.018)\end{array}$ & $\begin{array}{c}0.207^{* * *} \\
(0.052)\end{array}$ \\
\hline Own child's academic ability & $\begin{array}{l}-0.000 \\
(0.000)\end{array}$ & $\begin{array}{l}-0.000 \\
(0.000)\end{array}$ & $\begin{array}{c}-0.001^{*} \\
(0.000)\end{array}$ & $\begin{array}{c}0.009^{* * *} \\
(0.001)\end{array}$ \\
\hline Own child's school year & $\begin{array}{l}-0.004 \\
(0.004)\end{array}$ & $\begin{array}{l}-0.005 \\
(0.004)\end{array}$ & $\begin{array}{c}0.011 \\
(0.011)\end{array}$ & $\begin{array}{l}-0.012 \\
(0.029)\end{array}$ \\
\hline Own child is male & $\begin{array}{c}-0.004 \\
(0.007)\end{array}$ & $\begin{array}{l}-0.001 \\
(0.006)\end{array}$ & $\begin{array}{c}-0.027^{*} \\
(0.016)\end{array}$ & $\begin{array}{c}0.034 \\
(0.047)\end{array}$ \\
\hline Age of own child & $\begin{array}{c}0.003 \\
(0.004)\end{array}$ & $\begin{array}{c}0.005 \\
(0.004)\end{array}$ & $\begin{array}{c}-0.013 \\
(0.011)\end{array}$ & $\begin{array}{l}-0.014 \\
(0.029)\end{array}$ \\
\hline Foreign language at home & $\begin{array}{c}0.003 \\
(0.010)\end{array}$ & $\begin{array}{c}0.033^{* * *} \\
(0.010)\end{array}$ & $\begin{array}{c}0.015 \\
(0.023)\end{array}$ & $\begin{array}{l}-0.026 \\
(0.064)\end{array}$ \\
\hline Region FE & Yes & Yes & Yes & Yes \\
\hline Sample Mean & 0.11 & 0.08 & 0.17 & 0.00 \\
\hline R-squared & 0.019 & 0.024 & 0.023 & 0.077 \\
\hline Observations & 1633 & 1630 & 1638 & 1825 \\
\hline \multicolumn{5}{|c|}{$\begin{array}{l}\text { Notes: Standard errors in parentheses. }{ }^{*} \mathrm{p}<0.10,{ }^{* *} \mathrm{p}<0.05,{ }^{* * *} \mathrm{p}<0.01 \text {. All regressions } \\
\text { include a constant. Observations are weighted according to the age and gender of the } \\
\text { parent's own child and the education level of the responding parent. 'Time', 'Material' } \\
\text { and 'School' are the individual perceived returns to time investments, material investments } \\
\text { and school quality, respectively, while 'Mindset' is the extracted factor from the growth } \\
\text { mindset/malleability of skills questionnaire. 'High Income' equals } 1 \text { if the parent has above } \\
\text { median income. 'Sample mean' gives the mean of the dependent variable using only those } \\
\text { observations used in the relevant estimation. }\end{array}$} \\
\hline
\end{tabular}




\subsection{Do Perceived Returns Predict Current Parental Investments?}

Our data contains rich information on current parental investment decisions. We can use this information, together with the elicited returns, to investigate whether parental beliefs about the returns to investments are predictive of parents' current investment choices while controlling for a range of parent and child characteristics. In Table 9, we regress the time parents report to spend every week on different activities (in minutes) on the individual perceived returns to time investments. We find that parental beliefs about the returns to parental time investments are significantly associated with the amount of time parents spend on different activities with their children (at the $1 \%$ level). Overall, an increase in the perceived return by 10 percentage points is associated with parents spending 46 more minutes every week on these activities (column 5). In contrast to the common finding in the literature that more educated parents invest more time into their children, we do not find a significant positive effect of parental education on time invested. However, we do find some evidence that household income is positively related to time invested. We also find that time investments are increasing in the children's own ability, i.e. they are reinforcing in skills. In terms of household specialization, mothers seem to invest significantly more time than fathers.

Similarly, we find that parental beliefs about the returns to parental material investments significantly predict the amount parents spend on different educational resources every month (such as books, educational games etc.). Overall, an increase in the perceived return by 10 percentage points is associated with an increase in monthly spending by approximately $£ 14.8$ (Column 5 ), which is significant at the $1 \%$ level. When we use alternative measures to summarize how much time parents or how much money parents spend on their children (e.g. when we extract a factor from the money/time spent on the different categories), again we find a positive and significant association (see Columns 6 in the respective tables). In the case of material investments, we find that they are positively and significantly related to the education level, income and employment status of the parent. As for time investments, material investments are also reinforcing in children's skills.

Finally, we regress the quality of the school the child currently attends on individual perceived returns to high school quality. We do not find a significant association between these two variables. ${ }^{13}$ However, school quality can only be changed through rather large discrete investments, such as moving neighborhoods. In order to look at a more continuous measure, we look at the amount of school fees parents pay and find that the perceived returns to school quality significantly predict the amount of

\footnotetext{
${ }^{13}$ We also do not find any significant association if we perform an ordered probit analysis.
} 
school fees paid.

We perform several robustness checks and find that our results are robust to us excluding all those individuals from the analysis for whom the implied returns to any given type of investment are negative (see Tables A.5, A.6 and A.7 in the Appendix). They are also robust to us controlling for individual beliefs about returns to the other two types of investments (see Tables A.8, A.9 and A.10 in the Appendix). Overall, parental beliefs about the returns to investments are predictive of the educational investment decisions that parents make for their children. These results are consistent with a model in which parental beliefs play an important role in parental investment decisions.

\subsection{Beliefs about the Malleability of Skills}

In the previous sections, we document several interesting patterns regarding the heterogeneity in individual responses. Firstly, individuals differ substantially in their beliefs regarding the productivity or usefulness of different investments. Secondly, parents who perceive one type of investment as more productive are also more likely to believe that the other investments have a higher return. A natural question which emerges is why some parents perceive all investment types as being important while other parents perceive the returns to all types of investments to be low.

One hypothesis one might have is that there is an underlying reason which can explain individual beliefs about the returns to any type of investment made in children. For example, it could very well be that parents differ in their mindsets regarding whether children's skills are malleable in general and whether they are responsive to any type of input. To investigate this question in more detail, we administer an additional parental mindset questionnaire which aims to measure parents' beliefs about the malleability of children's skills. This questionnaire is inspired by the work of Dweck (2006) who documents that individuals differ substantially in their mindset regarding the malleability of their own intelligence.

To measure parental mindsets, we present parents with a series of items which pertain to the malleability of children's skills, and ask parents to rate these items on a Likert-type scale (e.g., My child develops at his/her own pace and there is not much I can do about that'). The full list of all questions can be found in Appendix B. We extract a factor from parents' responses and first investigate how the extracted factor correlates with the perceived returns to time investments, material investments and school quality calculated in Section 4.3. The results reveal that parental mindsets are indeed positively and significantly correlated with parental beliefs about the returns to time investments (corr $=0.173$, p- 
value $<0.001)$ as well as parental beliefs about the returns to school quality (corr $=0.137$, $p$-value $<0.001)$. Put differently, parents who do not perceive children's skills to be malleable in general also perceive the returns to investments to be lower. Column 4 of Table 8 documents which individual characteristics predict parental mindset. We note that fathers are significantly less likely to perceive their children's skills to be malleable through home inputs and that wealthier parents perceive their children's skills as significantly more malleable.

These results are important as previous studies have shown that it is possible to change the investments individuals make into their own skills by changing individual beliefs regarding the malleability of their skills (see, e.g., Alan, Boneva and Ertac 2015). Interventions that target parental beliefs about the malleability of their children's skills may hence be effective in altering parental beliefs about the returns to educational investments and may therefore encourage parents to invest more into their children.

\section{Conclusion}

To understand why some parents invest more into their children and to gain a better understanding of how parents might respond to policy changes, it is important to understand how parents perceive the returns to different types of investments. We elicit parental beliefs about returns to investments in terms of time, money, and school quality, as well as their perceptions about the complementarity or substitutability between these different inputs. Importantly, our research design allows us to relate perceived returns to actual investments made by parents.

Using a representative sample of parents in England, we find perceived returns to all three different types of investments to be positive and of considerable magnitude. We document that parents perceive the returns to 3 hours of weekly parental time investments or $£ 30$ of weekly material investments to matter more than moving a child to a better school. Moreover, we find that parents perceive school quality and material investments as complementary, i.e. parents perceive the returns to material investments to be higher if the child attends a high quality school. Interestingly, parents who perceive the returns to one type of investment to be high, are also more likely to perceive the returns to the other types of investments to be high. Importantly, we establish that parents who perceive the returns to investments to be higher also invest considerably more into their children. These results are consistent with parental beliefs playing a very important role in parental investment decisions.

The results of our study are important because they can help us identify bottlenecks which prevent 
parents from investing into their children. They can also help us shed more light on the question how policy changes may bring about changes in parental behavior. For instance, we find that parents perceive that the returns to material investments are higher if school quality is higher. Therefore, if a policy is introduced that improves school quality then our results suggest that parents are likely to also increase material investments in response to this change. While this is desirable in a sense that children would on average receive higher levels of investments, this may also deepen socioeconomic gaps in investment levels as more affluent parents have greater means to increase the material investments they make into their children.

When we look at what drives perceived returns, we find, perhaps surprisingly, that the perceived productivity of investments is not related to parental background. However, we find that the productivity of investment is positively related to beliefs about the malleability of skills in general. This suggests that one bottleneck to investments might be that some parents think that skills are not malleable. One promising avenue for policy could be to engage parents in training and information campaigns in which the idea is conveyed that skills are malleable and can be affected in the home environment. A similar intervention which targets the beliefs of school children has produced promising results in terms of the effort children exert to accumulate skills as well as students' performance on standardized tests (Alan, Boneva and Ertac 2015). Whether or not a home intervention that targets parental beliefs would be successful in raising parental investment levels and child outcomes is an open question that future research should address. 
Table 9: Determinants of weekly time investments (in minutes)

\begin{tabular}{|c|c|c|c|c|c|c|c|}
\hline & \multicolumn{6}{|c|}{ Weekly investments } & \multirow{2}{*}{$\begin{array}{c}\text { Factor } \\
\text { Activities }\end{array}$} \\
\hline & Reading & Helping & Talking & Playing & Other & Total & \\
\hline \multirow[t]{2}{*}{ Perceived returns (time) } & 37.428 & $208.715^{* * *}$ & 32.345 & 52.541 & $131.742^{* *}$ & $462.772^{* *}$ & $0.543^{* *}$ \\
\hline & $(36.386)$ & $(65.324)$ & $(96.236)$ & $(59.051)$ & $(53.546)$ & $(209.778)$ & $(0.212)$ \\
\hline \multirow[t]{2}{*}{ Male parent } & $-18.813^{* *}$ & -21.505 & $-108.247^{* * *}$ & 14.168 & -15.768 & $-150.166^{* * *}$ & $-0.127^{* *}$ \\
\hline & $(9.036)$ & $(15.710)$ & $(27.613)$ & $(18.764)$ & $(12.709)$ & $(58.008)$ & $(0.057)$ \\
\hline \multirow{2}{*}{ Age of parent } & -0.188 & -1.175 & -2.488 & $-3.395^{* * *}$ & 0.157 & $-7.089^{* *}$ & $-0.006^{*}$ \\
\hline & $(0.598)$ & $(0.845)$ & $(1.703)$ & $(1.104)$ & $(0.812)$ & $(3.585)$ & $(0.004)$ \\
\hline \multirow[t]{2}{*}{ Number of children } & 3.307 & 11.005 & -15.846 & 3.677 & -0.791 & 1.353 & 0.012 \\
\hline & $(5.276)$ & $(10.190)$ & $(16.537)$ & $(11.536)$ & $(8.296)$ & $(36.446)$ & $(0.035)$ \\
\hline \multirow[t]{2}{*}{ Other parent in household } & 13.984 & 16.348 & -5.178 & $47.416^{* *}$ & $30.544^{* *}$ & 103.113 & 0.120 \\
\hline & $(12.183)$ & $(22.869)$ & $(36.668)$ & $(19.506)$ & $(15.208)$ & $(75.744)$ & $(0.073)$ \\
\hline \multirow[t]{2}{*}{ Parent works full-time } & 8.434 & -11.378 & $-56.123^{* *}$ & -15.499 & 11.453 & -63.112 & -0.034 \\
\hline & $(8.644)$ & $(15.977)$ & $(26.690)$ & $(18.242)$ & $(13.631)$ & $(58.322)$ & $(0.057)$ \\
\hline \multirow[t]{2}{*}{ At least one parent has degree } & 0.845 & -17.925 & -24.176 & -4.353 & 2.958 & -42.651 & -0.036 \\
\hline & $(8.061)$ & $(13.753)$ & $(24.973)$ & $(17.113)$ & $(12.000)$ & $(53.354)$ & $(0.052)$ \\
\hline \multirow[t]{2}{*}{ Own child at private school } & 26.059 & 18.461 & $-92.071^{*}$ & 35.130 & 31.680 & 19.258 & 0.082 \\
\hline & $(19.425)$ & $(33.577)$ & $(47.232)$ & $(44.603)$ & $(30.642)$ & $(113.226)$ & $(0.120)$ \\
\hline \multirow[t]{2}{*}{ High income } & 0.856 & 11.653 & $45.911^{*}$ & 29.272 & 11.773 & $99.466^{*}$ & 0.084 \\
\hline & $(8.491)$ & $(15.520)$ & $(26.763)$ & $(19.553)$ & $(12.804)$ & $(58.766)$ & $(0.057)$ \\
\hline \multirow[t]{2}{*}{ Own child's academic ability } & $0.639^{* * *}$ & $1.206^{* * *}$ & $2.362^{* * *}$ & $1.028^{* *}$ & $1.864^{* * *}$ & $7.099^{* * *}$ & $0.007^{* * *}$ \\
\hline & $(0.211)$ & $(0.379)$ & $(0.705)$ & $(0.489)$ & $(0.304)$ & $(1.490)$ & $(0.001)$ \\
\hline \multirow[t]{2}{*}{ Own child's school year } & 4.960 & 10.753 & 9.474 & 8.914 & $15.828^{* *}$ & 49.929 & 0.054 \\
\hline & $(6.521)$ & $(9.466)$ & $(14.284)$ & $(12.712)$ & $(6.563)$ & $(35.232)$ & $(0.036)$ \\
\hline \multirow{2}{*}{ Own child is male } & -3.343 & -8.290 & -28.516 & 15.885 & -2.711 & -26.975 & -0.021 \\
\hline & $(7.655)$ & $(12.918)$ & $(23.624)$ & $(15.689)$ & $(11.548)$ & $(49.771)$ & $(0.048)$ \\
\hline \multirow[t]{2}{*}{ Age of own child } & $-18.996^{* * *}$ & -13.854 & -13.177 & $-27.263^{* *}$ & $-21.037^{* * *}$ & $-94.328^{* * *}$ & $-0.107^{* * *}$ \\
\hline & $(6.658)$ & $(9.536)$ & $(14.370)$ & $(12.948)$ & $(6.646)$ & $(35.800)$ & $(0.036)$ \\
\hline \multirow[t]{2}{*}{ Foreign language at home } & $29.996^{* *}$ & $55.694^{* * *}$ & $-65.436^{* *}$ & 26.279 & $65.117^{* * *}$ & 111.649 & $0.181^{* *}$ \\
\hline & $(12.738)$ & $(20.383)$ & $(31.135)$ & $(22.633)$ & $(16.987)$ & $(74.231)$ & $(0.075)$ \\
\hline Region FE & Yes & Yes & Yes & Yes & Yes & Yes & Yes \\
\hline Sample Mean & 117.37 & 276.78 & 616.28 & 297.11 & 184.32 & 1491.86 & -0.01 \\
\hline R-squared & 0.124 & 0.041 & 0.051 & 0.087 & 0.068 & 0.075 & 0.090 \\
\hline Observations & 1603 & 1603 & 1603 & 1603 & 1603 & 1603 & 1603 \\
\hline
\end{tabular}

Notes: Standard errors in parentheses. ${ }^{*} \mathrm{p}<0.10,{ }^{*} \mathrm{p}<0.05, * * * \mathrm{p}<0.01$. All regressions include a constant. Observations are weighted according to the age and gender of the parent's own child and the education level of the responding parent. For Columns (1)-(5), the dependent variable is the number of minutes spent (in minutes) with their own child per week on the five different activities shown in the column headings, while Column (6) treats the sum across all activities as the dependent variable. 'Reading' refers to time spent per week (in minutes) during term-time reading to/with the child, while 'Talking' refers to time spent talking with or listening to the child. 'Helping' denotes time spent helping or teaching the child, and 'Playing' refers to time spent playing with him/her (including sports). 'Other' refers to all other activities related to the child's education. In the final column, the dependent variable 'Activities' is the extracted first principal component from the responses to the five activities. 'Perceived returns (time)' refers to the perceived returns to time investments calculated in Section 4.3. 'High income' is a dummy variable equal to 1 if gross annual household income is above the median for our sample, and zero otherwise. 'Own child's academic ability' refers to the academic ability of the child perceived by the parent on a scale of $0-100$, where a higher response reflects higher perceived ability. 'Foreign language at home' denotes whether the parent speaks any language other than English at home. 'Sample mean' gives the mean of the dependent variable using only those observations used in the relevant estimation. 
Table 10: Determinants of monthly material investments (in $£ s$ )

\begin{tabular}{|c|c|c|c|c|c|c|}
\hline & \multicolumn{5}{|c|}{ Monthly investments } & \multirow{2}{*}{$\begin{array}{c}\text { Factor } \\
\text { Expenditure }\end{array}$} \\
\hline & Books & Educ. games & Societies & Tuition & Total & \\
\hline Perceived returns (material) & $\begin{array}{l}54.445^{* *} \\
(24.005)\end{array}$ & $\begin{array}{c}30.249^{* * *} \\
(11.124)\end{array}$ & $\begin{array}{c}31.127 \\
(20.147)\end{array}$ & $\begin{array}{c}32.178 \\
(21.477)\end{array}$ & $\begin{array}{c}148.000^{* * *} \\
(52.129)\end{array}$ & $\begin{array}{c}1.581^{* * *} \\
(0.538)\end{array}$ \\
\hline Male parent & $\begin{array}{l}-0.484 \\
(1.413)\end{array}$ & $\begin{array}{c}0.123 \\
(1.432)\end{array}$ & $\begin{array}{l}-2.846 \\
(5.376)\end{array}$ & $\begin{array}{l}1.408 \\
(2.814)\end{array}$ & $\begin{array}{l}-1.800 \\
(7.408)\end{array}$ & $\begin{array}{l}-0.008 \\
(0.051)\end{array}$ \\
\hline Age of parent & $\begin{array}{c}0.045 \\
(0.096)\end{array}$ & $\begin{array}{l}-0.106 \\
(0.102)\end{array}$ & $\begin{array}{c}0.888^{* * *} \\
(0.235)\end{array}$ & $\begin{array}{c}0.097 \\
(0.174)\end{array}$ & $\begin{array}{c}0.923^{* *} \\
(0.409)\end{array}$ & $\begin{array}{c}0.003 \\
(0.003)\end{array}$ \\
\hline Number of children & $\begin{array}{c}1.552 \\
(1.140)\end{array}$ & $\begin{array}{c}0.975 \\
(1.456)\end{array}$ & $\begin{array}{c}2.618 \\
(2.967)\end{array}$ & $\begin{array}{c}0.766 \\
(2.128)\end{array}$ & $\begin{array}{c}5.911 \\
(5.283)\end{array}$ & $\begin{array}{c}0.052 \\
(0.044)\end{array}$ \\
\hline Other parent in household & $\begin{array}{c}0.297 \\
(1.741)\end{array}$ & $\begin{array}{l}-0.845 \\
(2.196)\end{array}$ & $\begin{array}{l}-0.511 \\
(5.017)\end{array}$ & $\begin{array}{c}2.821 \\
(2.277)\end{array}$ & $\begin{array}{c}1.761 \\
(8.362)\end{array}$ & $\begin{array}{c}0.006 \\
(0.066)\end{array}$ \\
\hline Parent works full-time & $\begin{array}{c}1.641 \\
(1.166)\end{array}$ & $\begin{array}{c}3.973^{* * *} \\
(1.285)\end{array}$ & $\begin{array}{c}0.530 \\
(5.298)\end{array}$ & $\begin{array}{l}5.160^{* *} \\
(2.161)\end{array}$ & $\begin{array}{l}11.304^{*} \\
(6.840)\end{array}$ & $\begin{array}{l}0.112^{* *} \\
(0.044)\end{array}$ \\
\hline At least one parent has degree & $\begin{array}{c}1.704 \\
(1.508)\end{array}$ & $\begin{array}{c}0.973 \\
(1.447)\end{array}$ & $\begin{array}{c}17.121^{* * *} \\
(4.395)\end{array}$ & $\begin{array}{c}7.344^{* * *} \\
(2.466)\end{array}$ & $\begin{array}{c}27.141^{* * *} \\
(6.716)\end{array}$ & $\begin{array}{c}0.140^{* * *} \\
(0.052)\end{array}$ \\
\hline Own child goes to state school & $\begin{array}{l}-0.875 \\
(3.411)\end{array}$ & $\begin{array}{l}-7.948 \\
(5.009)\end{array}$ & $\begin{array}{c}-47.289^{* *} \\
(20.220)\end{array}$ & $\begin{array}{c}-22.938^{* *} \\
(8.952)\end{array}$ & $\begin{array}{c}-79.050^{* * *} \\
(26.456)\end{array}$ & $\begin{array}{c}-0.413^{* *} \\
(0.163)\end{array}$ \\
\hline High income & $\begin{array}{c}4.362^{* * *} \\
(1.498)\end{array}$ & $\begin{array}{l}3.293^{* *} \\
(1.602)\end{array}$ & $\begin{array}{c}19.424^{* * *} \\
(4.481)\end{array}$ & $\begin{array}{c}3.002 \\
(2.199)\end{array}$ & $\begin{array}{c}30.081^{* * *} \\
(6.877)\end{array}$ & $\begin{array}{c}0.200^{* * *} \\
(0.054)\end{array}$ \\
\hline Own child's academic ability & $\begin{array}{c}0.108^{* * *} \\
(0.036)\end{array}$ & $\begin{array}{l}0.064^{* *} \\
(0.032)\end{array}$ & $\begin{array}{c}0.359^{* * *} \\
(0.102)\end{array}$ & $\begin{array}{l}-0.092 \\
(0.060)\end{array}$ & $\begin{array}{c}0.439^{* * *} \\
(0.158)\end{array}$ & $\begin{array}{c}0.003^{* * *} \\
(0.001)\end{array}$ \\
\hline Own child's school year & $\begin{array}{c}0.423 \\
(1.295)\end{array}$ & $\begin{array}{l}2.739^{* *} \\
(1.325)\end{array}$ & $\begin{array}{l}4.012^{*} \\
(2.235)\end{array}$ & $\begin{array}{c}1.941 \\
(1.879)\end{array}$ & $\begin{array}{l}9.117^{*} \\
(4.845)\end{array}$ & $\begin{array}{c}0.070 \\
(0.043)\end{array}$ \\
\hline Own child is male & $\begin{array}{c}1.518 \\
(1.191)\end{array}$ & $\begin{array}{l}3.318^{* *} \\
(1.341)\end{array}$ & $\begin{array}{l}-3.675 \\
(4.314)\end{array}$ & $\begin{array}{c}1.479 \\
(2.091)\end{array}$ & $\begin{array}{c}2.640 \\
(6.078)\end{array}$ & $\begin{array}{c}0.067 \\
(0.044)\end{array}$ \\
\hline Age of own child & $\begin{array}{l}-0.164 \\
(1.380)\end{array}$ & $\begin{array}{c}-3.421^{* * *} \\
(1.290)\end{array}$ & $\begin{array}{c}-4.894^{* *} \\
(2.265)\end{array}$ & $\begin{array}{l}-1.567 \\
(1.911)\end{array}$ & $\begin{array}{c}-10.047^{* *} \\
(4.909)\end{array}$ & $\begin{array}{l}-0.077^{*} \\
(0.044)\end{array}$ \\
\hline Foreign language at home & $\begin{array}{c}3.284 \\
(2.649)\end{array}$ & $\begin{array}{l}5.654^{*} \\
(2.985)\end{array}$ & $\begin{array}{c}3.696 \\
(6.212)\end{array}$ & $\begin{array}{c}6.918 \\
(4.604)\end{array}$ & $\begin{array}{l}19.552^{*} \\
(10.946)\end{array}$ & $\begin{array}{l}0.183^{* *} \\
(0.090)\end{array}$ \\
\hline Region FE & Yes & Yes & Yes & Yes & Yes & Yes \\
\hline Sample Mean & $£ 14.64$ & $£ 11.90$ & $£ 48.64$ & $£ 12.32$ & $£ 87.50$ & 0.01 \\
\hline R-squared & 0.082 & 0.067 & 0.084 & 0.062 & 0.116 & 0.108 \\
\hline Observations & 1628 & 1628 & 1628 & 1628 & 1628 & 1628 \\
\hline
\end{tabular}

Notes: Standard errors in parentheses. ${ }^{*} \mathrm{p}<0.10$, ** $\mathrm{p}<0.05$, *** $\mathrm{p}<0.01$. All regressions include a constant. Observations are weighted according to the age and gender of the parent's own child and the education level of the responding parent. For Columns (1)-(4), the dependent variable is the amount spent per month (in $£$ s) on the respective category given by the column headings. 'Books' refers to expenditures on books other than school books, while 'Educ. games' denotes spending on educational games and toys. 'Societies' denotes monthly expenditure on sports clubs, music lessons and other societies/clubs, while 'Tuition' refers to private tuition. Column (5) treats the sum of these four expenditure categories (denoted as 'Total') as the dependent variable. In the final column, the dependent variable 'Expenditure' is the extracted first principal component from the responses to the four expenditure categories. 'Perceived returns (material)' refers to the perceived returns to time investments calculated in Section 4.3. 'High income' is a dummy variable equal to 1 if gross annual household income is above the median for our sample, and zero otherwise. 'Own child's academic ability' refers to the academic ability of the child perceived by the parent on a scale of $0-100$, where a higher response reflects higher perceived ability. 'Foreign language at home' denotes whether the parent speaks any language other than English at home. 'Sample mean' gives the mean of the dependent variable using only those observations used in the relevant estimation. 
Table 11: Determinants of school quality investments

\begin{tabular}{|c|c|c|}
\hline & School & Fees \\
\hline Perceived returns (quality) & $\begin{array}{c}0.077 \\
(0.067)\end{array}$ & $\begin{array}{l}82.356^{*} \\
(48.747)\end{array}$ \\
\hline Male parent & $\begin{array}{l}-0.003 \\
(0.039)\end{array}$ & $\begin{array}{c}14.413 \\
(19.990)\end{array}$ \\
\hline Age of parent & $\begin{array}{c}0.005^{* *} \\
(0.002)\end{array}$ & $\begin{array}{l}2.767^{* *} \\
(1.177)\end{array}$ \\
\hline Number of children & $\begin{array}{c}0.008 \\
(0.023)\end{array}$ & $\begin{array}{c}-4.067 \\
(10.099)\end{array}$ \\
\hline Other parent in household & $\begin{array}{l}-0.006 \\
(0.049)\end{array}$ & $\begin{array}{c}0.469 \\
(15.245)\end{array}$ \\
\hline Parent works full-time & $\begin{array}{l}-0.056 \\
(0.039)\end{array}$ & $\begin{array}{c}-12.805 \\
(19.989)\end{array}$ \\
\hline At least one parent has degree & $\begin{array}{c}0.030 \\
(0.035)\end{array}$ & $\begin{array}{c}2.994 \\
(17.254)\end{array}$ \\
\hline High income & $\begin{array}{c}0.121^{* * *} \\
(0.036)\end{array}$ & $\begin{array}{c}71.546^{* * *} \\
(16.387)\end{array}$ \\
\hline Own child's academic ability & $\begin{array}{c}0.004^{* * *} \\
(0.001)\end{array}$ & $\begin{array}{c}0.473 \\
(0.326)\end{array}$ \\
\hline Own child's school year & $\begin{array}{c}0.014 \\
(0.018)\end{array}$ & $\begin{array}{l}-0.189 \\
(7.180)\end{array}$ \\
\hline Own child is male & $\begin{array}{c}0.012 \\
(0.033)\end{array}$ & $\begin{array}{c}4.888 \\
(15.377)\end{array}$ \\
\hline Age of own child & $\begin{array}{l}-0.022 \\
(0.018)\end{array}$ & $\begin{array}{c}3.352 \\
(8.054)\end{array}$ \\
\hline Foreign language at home & $\begin{array}{c}0.067 \\
(0.043) \\
\end{array}$ & $\begin{array}{c}33.114 \\
(24.582) \\
\end{array}$ \\
\hline Region FE & Yes & Yes \\
\hline Sample Mean & 3.22 & $£ 59.89$ \\
\hline R-squared & 0.048 & 0.050 \\
\hline Observations & 1558 & 1647 \\
\hline
\end{tabular}

Notes: Standard errors in parentheses. $* \mathrm{p}<0.10, * * \mathrm{p}<0.05$, $* * * \mathrm{p}<0.01$. Standard errors are clustered at the parent level. All regressions include a constant. Observations are weighted according to the age and gender of the parent's own child and the education level of the responding parent. The dependent variable 'School' is a discrete variable based on the Ofsted rating of the child's school. 'School' takes value 1 if the school is rated as 'Inadequate', 2 if 'Satisfactory/Requires improvement', 3 if 'Good' and 4 if 'Outstanding'. 'Fees' refers to the amount spent per month (in £s) on school fees. 'Perceived returns (school)' refers to the perceived returns to school quality calculated in Section 4.3. 'High income' is a dummy variable equal to 1 if gross annual household income is above the median for our sample, and zero otherwise. 'Own child's academic ability' refers to the academic ability of the child perceived by the parent on a scale of $0-100$, where a higher response reflects higher perceived ability. 'Foreign language at home' denotes whether the parent speaks any language other than English at home. 'Sample mean' gives the mean of the dependent variable using only those observations used in the relevant estimation. 


\section{References}

Abramitzky, Ran, and Victor Lavy. 2014. "How responsive is investment in schooling to changes in redistributive policies and in returns?" Econometrica, 82(4): 1241-1272.

Alan, Sule, Teodora Boneva, and Seda Ertac. 2015. "Ever Failed, Try Again, Succeed Better: Results from a Randomized Educational Intervention on Grit." HCEO Working Paper No. 2015-009.

Almas, Ingvild, Alexander Cappelen, Kjell Salvanes, Erik Sorensen, and Bertil Tungodden. 2016. "What explains the gender gap in college track dropout? Experimental and administrative evidence." American Economic Review: Papers 83 Proceedings, 106(5): 296-302.

Arcidiacono, Peter. 2004. "Ability Sorting and the Returns to College Major." Journal of Econometrics, 121(1): 343-375.

Arcidiacono, Peter, V Joseph Hotz, and Songman Kang. 2012. "Modeling College Major Choices using Elicited Measures of Expectations and Counterfactuals." Journal of Econometrics, 166(1): 3-16.

Arcidiacono, Peter, V Joseph Hotz, Arnaud Maurel, and Teresa Romano. 2014. "Recovering ex ante returns and preferences for occupations using subjective expectations data." National Bureau of Economic Research.

Attanasio, Orazio, and Katja Kaufmann. 2014. "Education Choices and Returns to Schooling: Intra-household Decision Making, Gender and Subjective Expectations." Journal of Development Economics, 109: 203-216.

Attanasio, Orazio, and Katja Kaufmann. 2017. "Education choices and returns on the labor and marriage markets: Evidence from data on subjective expectations." Unpublished manuscript.

Attanasio, Orazio, Costas Meghir, and Emily Nix. 2015. "Human Capital Development and Parental Investment in India." NBER Working Paper No. 21740.

Attanasio, Orazio, Flavio Cunha, and Pamela Jervis. 2016. "Eliciting beliefs about the production function." Unpublished manuscript.

Attanasio, Orazio, Sally Grantham-McGregor, Emla Fitzsimons, Marta Rubio-Codina, Costas Meghir, et al. 2013. "Enriching the home environment of low-income families in Colombia: a strategy to promote child development at scale." Early Childhood Matters. 
Attanasio, Orazio, Sarah Cattan, Emla Fitzsimons, Costas Meghir, and Marta RubioCodina. 2015. "Estimating the production function for human capital: Results from a randomized control trial in Colombia." NBER Working Paper No. 20965.

Baker, Rachel, Eric Bettinger, Brian Jacob, and Ioana Marinescu. 2017. "The effect of labor market information on community college students' major choice." NBER Working Paper 23333.

Becker, Gary S, and Nigel Tomes. 1979. "An equilibrium theory of the distribution of income and intergenerational mobility." The Journal of Political Economy, 1153-1189.

Becker, Gary S, and Nigel Tomes. 1986. "Human Capital and the Rise and Fall of Families." Journal of Labor Economics, 4(3 pt 2): 1-39.

Beffy, Magali, Denis Fougere, and Arnaud Maurel. 2012. "Choosing the field of study in postsecondary education: Do expected earnings matter?" Review of Economics and Statistics, 94(1): $334-347$.

Belfield, Chris, Teodora Boneva, Christopher Rauh, and Jonathan Shaw. forthcoming. "What drives enrollment gaps in further education? The role of beliefs in sequential schooling decisions." Economica.

Biroli, Pietro, Teodora Boneva, Akash Raja, and Christopher Rauh. 2018. "Parental Beliefs about Returns to Child Health Investments." HCEO working paper 2018-008.

Boneva, Teodora, and Christopher Rauh. 2017. "Socio-economic Gaps in University Enrollment: The Role of Perceived Pecuniary and Non-Pecuniary Returns." HCEO Working Paper 2017-080.

Boneva, Teodora, and Christopher Rauh. 2018. "Parental Beliefs about Returns to Educational Investments - The Later the Better?" Journal of the European Economic Association, 16(6): 16691711.

Carneiro, Pedro, Costas Meghir, and Matthias Parey. 2013. "Maternal education, home environments, and the development of children and adolescents." Journal of the European Economic Association, 11(s1): 123-160.

Caucutt, Elizabeth M, Lance Lochner, and Youngmin Park. 2017. "Correlation, Consumption, Confusion, or Constraints: Why do Poor Children Perform so Poorly?" The Scandinavian Journal of Economics, 119(1): 102-147. 
Cooksey, Elizabeth C, and Michelle M Fondell. 1996. "Spending time with his kids: Effects of family structure on fathers' and children's lives." Journal of Marriage and the Family, 693-707.

Cunha, Flávio. 2014. "Gaps in early investments in children." Working Paper, University of Pennsylvania.

Cunha, Flávio, Irma Elo, and Jennifer Culhane. 2013. "Eliciting maternal expectations about the technology of cognitive skill formation." NBER Working Paper No. 19144.

Cunha, Flávio, James J Heckman, and Susanne M Schennach. 2010. "Estimating the technology of cognitive and noncognitive skill formation." Econometrica, 78(3): 883-931.

Delavande, Adeline, and Basit Zafar. 2014. "University choice: the role of expected earnings, non-pecuniary outcomes, and financial constraints." FRB of New York Staff Report 683.

Dizon-Ross, Rebecca. 2018. "Parents' perceptions and children's education: Experimental evidence from Malawi." NBER Working Paper No 24610.

Dominitz, Jeff, and Charles Manski. 1996. "Eliciting Student Expectations of the Returns to Schooling." Journal of Human Resources, 31(1): 1-26.

Dweck, Carol. 2006. Mindset: The new psychology of success. Random House.

Giustinelli, Pamela. 2016. "Group Decision Making with Uncertain Outcomes: Unpacking ChildParent Choice of the High School Track." International Economic Review, 57(2): 573-602.

Guryan, Jonathan, Erik Hurst, and Melissa Kearney. 2008. "Parental Education and Parental Time with Children." The Journal of Economic Perspectives, 22(3): 23-46.

Hastings, Justine, Christopher Neilson, Anely Ramirez, and Seth Zimmerman. 2016. "(Un)informed college and major choice: Evidence from linked survey and administrative data." Economics of Education Review, 51: 136-151.

Jensen, Robert. 2010. "The (perceived) returns to education and the demand for schooling." The Quarterly Journal of Economics, 125(2): 515-548.

Kaufmann, Katja Maria. 2014. "Understanding the income gradient in college attendance in Mexico: The role of heterogeneity in expected returns." Quantitative Economics, 5(3): 583-630. 
Kinsler, Josh, and Ronni Pavan. 2016. "Parental beliefs and investment in children: The distortionary impact of schools." HCEO working paper 2016-029.

Lareau, Annette. 2011. Unequal childhoods: Class, race, and family life. Univ of California Press.

Lergetporer, Philipp, Katharina Werner, and Ludger Woessmann. 2018. "Does ignorance of economic returns and costs explain the educational aspiration gap? Evidence from representative survey experiments." CESifo Working Paper No. 7000.

Manski, Charles. 2004. "Measuring Expectations." Econometrica, 72(5): 1329-1376.

Montmarquette, Claude, Kathy Cannings, and Sophie Mahseredjian. 2002. "How Do Young People Choose College Majors?" Economics of Education Review, 21: 543-556.

Putnam, Robert D. 2015. Our kids: The American dream in crisis. Simon and Schuster.

Stinebrickner, Ralph, and Todd R Stinebrickner. 2014. "A Major in Science? Initial Beliefs and Final Outcomes for College Major and Dropout." The Review of Economic Studies, 81(1): 426-472.

Wiswall, Matthew, and Basit Zafar. 2015a. "Determinants of college major choice: Identification using an information experiment." The Review of Economic Studies, 82(2): 791-824.

Wiswall, Matthew, and Basit Zafar. 2015b. "How do college students respond to public information about earnings?" Journal of Human Capital, 9(2): 117-169.

Wiswall, Matthew, and Basit Zafar. 2017. "Preference for the workplace, human capital and gender." Quarterly Journal of Economics.

Zafar, Basit. 2013. "College major choice and the gender gap." Journal of Human Resources, 48(3): 545-595. 


\section{Appendix A: Supplementary Analysis}

Table A.1: Ofsted rating of own child's school and national distribution

\begin{tabular}{lccc}
\hline Ofsted rating & $\mathrm{N}$ & Percent & National Distribution \% \\
\hline Outstanding & 614 & 31.29 & 21 \\
Good & 1050 & 53.52 & 68 \\
Satisfactory/Requires Improvement & 166 & 8.46 & 9 \\
Inadequate & 16 & 0.82 & 2 \\
Don't know & 116 & 5.91 & - \\
\hline
\end{tabular}

Table A.2: Parental time spent with child (in minutes)

\begin{tabular}{lccccccc}
\hline Time investment & Weekday Weekend & $\begin{array}{l}\text { Week } \\
\text { total }\end{array}$ & SD & Min & Max & Median \\
\hline Reading to/with child & 16.82 & 17.16 & 118.39 & 158.22 & 0 & 1700 & 85 \\
Talking to/with child & 75.97 & 115.9 & 611.67 & 454.94 & 0 & 2100 & 500 \\
Helping child with studies & 36.54 & 47.17 & 277.03 & 254.01 & 0 & 2100 & 210 \\
Playing with child & 32.81 & 68.86 & 301.74 & 322.08 & 0 & 2100 & 220 \\
Other educational activities & 23.99 & 33.67 & 187.31 & 244.06 & 0 & 2100 & 120 \\
\hline Total time & 186.12 & 282.75 & 1496.13 & 1013.45 & 0 & 5480 & 1285 \\
\hline
\end{tabular}

Table A.3: Material investments per month (in pounds)

\begin{tabular}{lcccc}
\hline \multicolumn{1}{c}{ Variable } & Mean & SD & Min & Max \\
\hline & & & & \\
Books (exc. school books) & 14.393 & 27.469 & 0 & 530 \\
Educational games and toys & 12.713 & 52.621 & 0 & 2000 \\
Societies & 48.348 & 99.652 & 0 & 2000 \\
Private tuition & 12.309 & 69.984 & 0 & 2000 \\
School fees & 62.849 & 381.339 & 0 & 4000 \\
\hline Total expenditure & 150.611 & 465.123 & 0 & 6700 \\
\hline
\end{tabular}


Figure A.1: Distributions of individual perceived returns

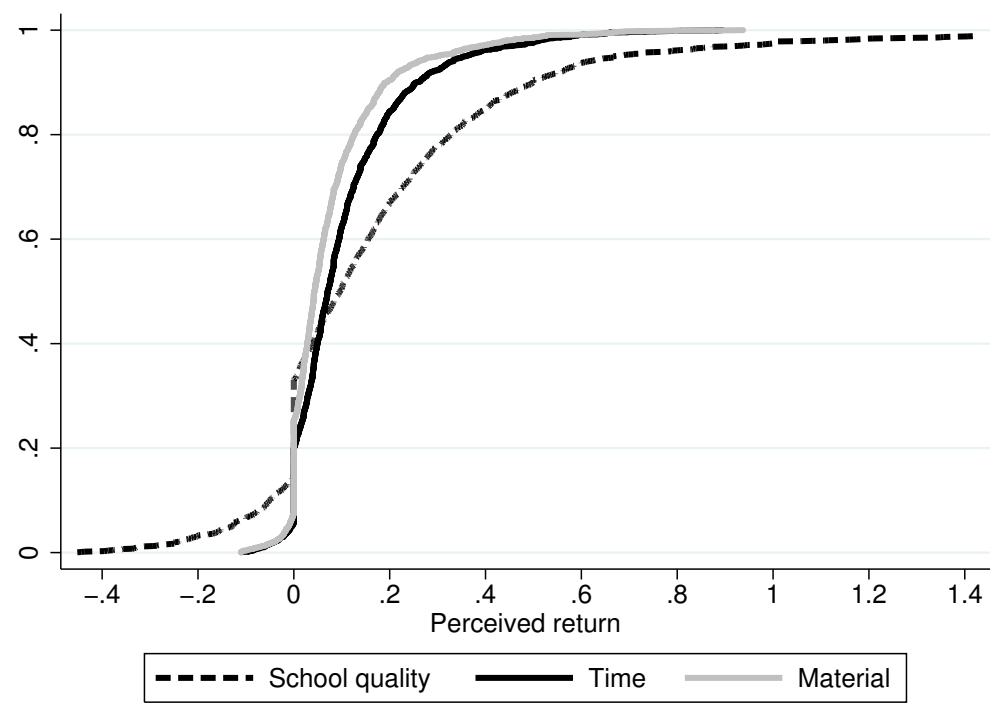


Figure A.2: Joint distributions of individual perceived returns

A: Time and material
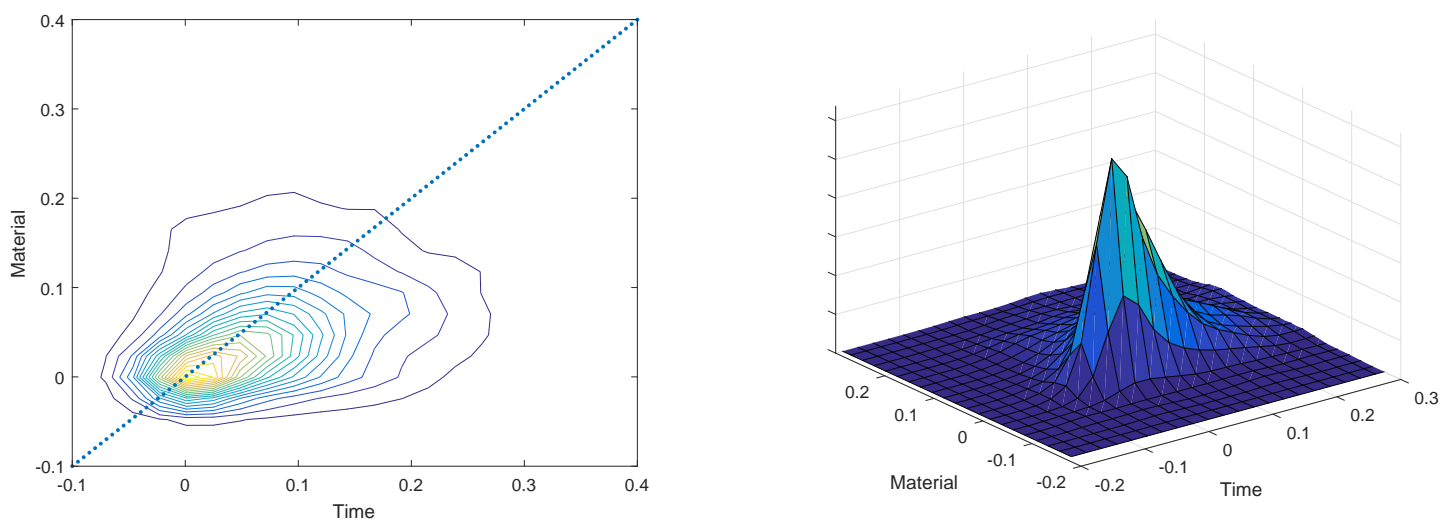

B: Time and school
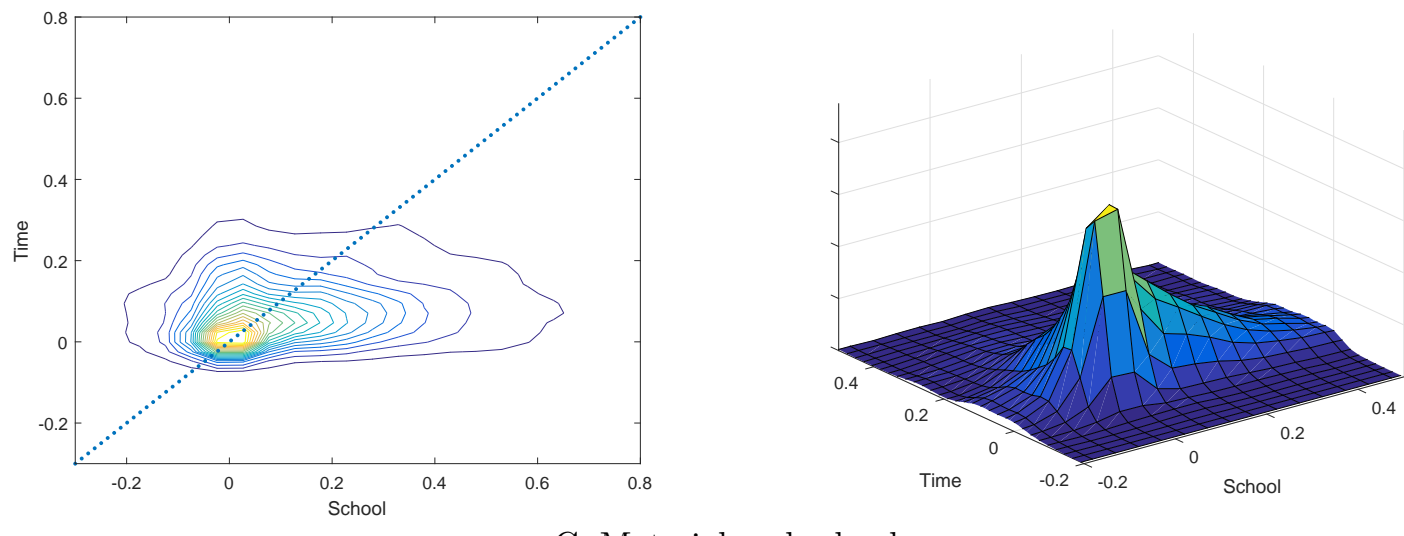

C: Material and school
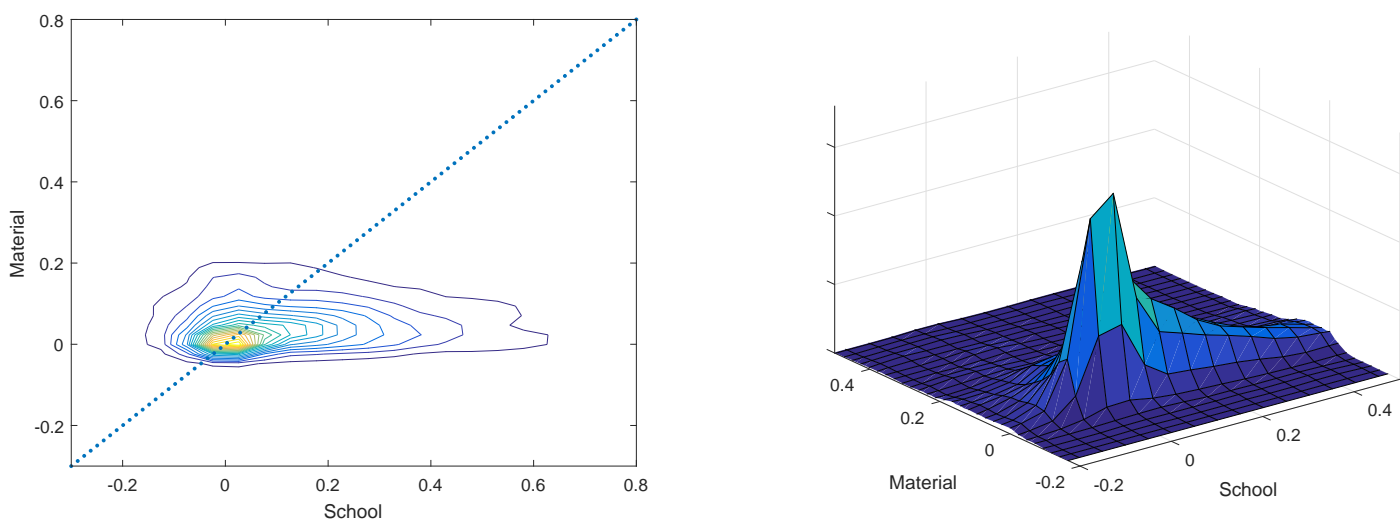
Table A.4: Determinants of perceived returns (2)

\begin{tabular}{|c|c|c|c|c|}
\hline & Time & Material & School & Mindset \\
\hline Male parent & $\begin{array}{l}-0.001 \\
(0.008)\end{array}$ & $\begin{array}{c}-0.002 \\
(0.008)\end{array}$ & $\begin{array}{c}-0.048^{* *} \\
(0.019)\end{array}$ & $\begin{array}{c}-0.176^{* * *} \\
(0.057)\end{array}$ \\
\hline Age of parent & $\begin{array}{c}-0.001^{*} \\
(0.000)\end{array}$ & $\begin{array}{c}0.000 \\
(0.000)\end{array}$ & $\begin{array}{c}0.001 \\
(0.001)\end{array}$ & $\begin{array}{c}0.017^{* * *} \\
(0.003)\end{array}$ \\
\hline Number of children & $\begin{array}{l}-0.002 \\
(0.005)\end{array}$ & $\begin{array}{l}-0.001 \\
(0.005)\end{array}$ & $\begin{array}{l}-0.002 \\
(0.013)\end{array}$ & $\begin{array}{c}-0.099^{* * *} \\
(0.033)\end{array}$ \\
\hline Other parent in household & $\begin{array}{c}0.004 \\
(0.011)\end{array}$ & $\begin{array}{l}-0.003 \\
(0.010)\end{array}$ & $\begin{array}{c}0.025 \\
(0.023)\end{array}$ & $\begin{array}{l}-0.009 \\
(0.072)\end{array}$ \\
\hline Parent works full-time & $\begin{array}{c}-0.013 \\
(0.008)\end{array}$ & $\begin{array}{c}-0.005 \\
(0.007)\end{array}$ & $\begin{array}{c}0.027 \\
(0.019)\end{array}$ & $\begin{array}{c}-0.081 \\
(0.056)\end{array}$ \\
\hline At least one parent has degree & $\begin{array}{l}-0.001 \\
(0.007)\end{array}$ & $\begin{array}{c}-0.006 \\
(0.007)\end{array}$ & $\begin{array}{c}0.011 \\
(0.017)\end{array}$ & $\begin{array}{c}-0.001 \\
(0.052)\end{array}$ \\
\hline Own child goes to private school & $\begin{array}{l}-0.005 \\
(0.015)\end{array}$ & $\begin{array}{c}0.014 \\
(0.017)\end{array}$ & $\begin{array}{c}0.059 \\
(0.045)\end{array}$ & $\begin{array}{c}0.084 \\
(0.128)\end{array}$ \\
\hline 2nd income quartile & $\begin{array}{l}-0.007 \\
(0.010)\end{array}$ & $\begin{array}{c}0.003 \\
(0.009)\end{array}$ & $\begin{array}{l}-0.024 \\
(0.024)\end{array}$ & $\begin{array}{c}0.116^{*} \\
(0.069)\end{array}$ \\
\hline 3rd income quartile & $\begin{array}{c}0.003 \\
(0.010)\end{array}$ & $\begin{array}{c}0.002 \\
(0.009)\end{array}$ & $\begin{array}{l}-0.011 \\
(0.022)\end{array}$ & $\begin{array}{c}0.210^{* * *} \\
(0.064)\end{array}$ \\
\hline 4th income quartile & $\begin{array}{c}-0.005 \\
(0.010)\end{array}$ & $\begin{array}{c}-0.011 \\
(0.009)\end{array}$ & $\begin{array}{c}0.002 \\
(0.024)\end{array}$ & $\begin{array}{c}0.332^{* * *} \\
(0.074)\end{array}$ \\
\hline Own child's academic ability & $\begin{array}{c}-0.000 \\
(0.000)\end{array}$ & $\begin{array}{c}-0.000 \\
(0.000)\end{array}$ & $\begin{array}{c}-0.001^{*} \\
(0.000)\end{array}$ & $\begin{array}{c}0.009^{* * *} \\
(0.001)\end{array}$ \\
\hline Own child's school year & $\begin{array}{c}-0.004 \\
(0.004)\end{array}$ & $\begin{array}{l}-0.005 \\
(0.004)\end{array}$ & $\begin{array}{c}0.011 \\
(0.011)\end{array}$ & $\begin{array}{l}-0.014 \\
(0.029)\end{array}$ \\
\hline Own child is male & $\begin{array}{l}-0.004 \\
(0.007)\end{array}$ & $\begin{array}{c}-0.001 \\
(0.006)\end{array}$ & $\begin{array}{l}-0.027^{*} \\
(0.016)\end{array}$ & $\begin{array}{c}0.032 \\
(0.047)\end{array}$ \\
\hline Age of own child & $\begin{array}{c}0.003 \\
(0.004)\end{array}$ & $\begin{array}{c}0.005 \\
(0.004)\end{array}$ & $\begin{array}{l}-0.013 \\
(0.011)\end{array}$ & $\begin{array}{l}-0.012 \\
(0.030)\end{array}$ \\
\hline Foreign language at home & $\begin{array}{c}0.003 \\
(0.010)\end{array}$ & $\begin{array}{c}0.033^{* * *} \\
(0.010)\end{array}$ & $\begin{array}{c}0.014 \\
(0.023)\end{array}$ & $\begin{array}{l}-0.021 \\
(0.064)\end{array}$ \\
\hline Region FE & Yes & Yes & Yes & Yes \\
\hline Sample Mean & 0.11 & 0.08 & 0.17 & 0.00 \\
\hline R-squared & 0.019 & 0.024 & 0.023 & 0.077 \\
\hline Observations & 1633 & 1630 & 1638 & 1825 \\
\hline
\end{tabular}

Notes: Standard errors in parentheses. ${ }^{*} \mathrm{p}<0.10,{ }^{* *} \mathrm{p}<0.05,{ }^{* * *} \mathrm{p}<0.01$. All regressions include a constant. Observations are weighted according to the age and gender of the parent's own child and the education level of the responding parent. 'Time', 'Material' and 'School' are the individual perceived returns to time investments, material investments and school quality, respectively, while 'Mindset' is the extracted factor from the growth mindset/malleability of skills questionnaire. 'Sample mean' gives the mean of the dependent variable using only those observations used in the relevant estimation. 
Table A.5: Determinants of weekly time investments (in minutes) - Robustness I

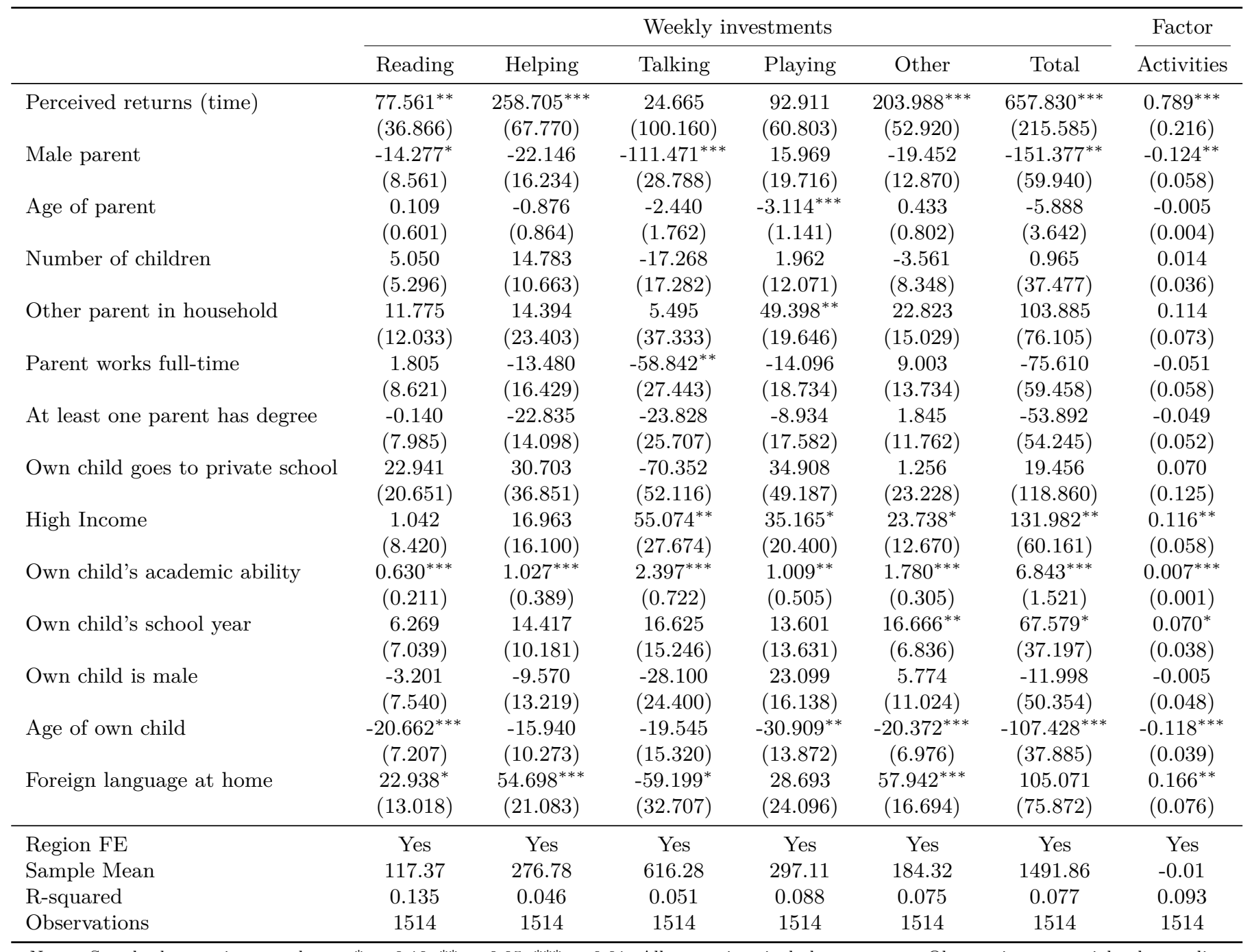

Notes: Standard errors in parentheses. ${ }^{*} \mathrm{p}<0.10,{ }^{* *} \mathrm{p}<0.05,{ }^{* * *} \mathrm{p}<0.01$. All regressions include a constant. Observations are weighted according to the age and gender of the parent's own child and the education level of the responding parent. The analysis is limited to those individuals for whom the implied perceived returns to time investments are non-negative. For Columns (1)-(5), the dependent variable is the number of minutes spent (in minutes) with their own child per week on the five different activities shown in the column headings, while Column (6) treats the sum across all activities as the dependent variable. 'Reading' refers to time spent per week (in minutes) during term-time reading to/with the child, while 'Talking' refers to time spent talking with or listening to the child. 'Helping' denotes time spent helping or teaching the child, and 'Playing' refers to time spent playing with him/her (including sports). 'Other' refers to all other activities related to the child's education. In the final column, the dependent variable 'Activities' is the extracted first principal component from the responses to the five activities. 'Perceived returns (time)' refers to the perceived returns to time investments calculated in Section 4.3. 'High income' is a dummy variable equal to 1 if gross annual household income is above the median for our sample, and zero otherwise. 'Own child's academic ability' refers to the academic ability of the child perceived by the parent on a scale of $0-100$, where a higher response reflects higher perceived ability. 'Foreign language at home' denotes whether the parent speaks any language other than English at home. 'Sample mean' gives the mean of the dependent variable using only those observations used in the relevant estimation. 
Table A.6: Determinants of monthly material investments (in $£ s)$ - Robustness I

\begin{tabular}{|c|c|c|c|c|c|c|}
\hline & \multicolumn{5}{|c|}{ Monthly investments } & \multirow{2}{*}{$\begin{array}{c}\text { Factor } \\
\text { Expenditure }\end{array}$} \\
\hline & Books & Educ. games & Societies & Tuition & Total & \\
\hline Perceived returns (material) & $\begin{array}{l}63.925^{* *} \\
(25.223)\end{array}$ & $\begin{array}{c}39.548^{* * *} \\
(11.366)\end{array}$ & $\begin{array}{l}35.446^{*} \\
(21.446)\end{array}$ & $\begin{array}{l}42.357^{*} \\
(22.711)\end{array}$ & $\begin{array}{c}181.277^{* * *} \\
(53.901)\end{array}$ & $\begin{array}{c}1.934^{* * *} \\
(0.554)\end{array}$ \\
\hline Male parent & $\begin{array}{l}-1.476 \\
(1.412)\end{array}$ & $\begin{array}{l}-0.649 \\
(1.290)\end{array}$ & $\begin{array}{l}-3.918 \\
(5.856)\end{array}$ & $\begin{array}{c}0.220 \\
(2.968)\end{array}$ & $\begin{array}{l}-5.823 \\
(7.842)\end{array}$ & $\begin{array}{l}-0.045 \\
(0.051)\end{array}$ \\
\hline Age of parent & $\begin{array}{c}0.091 \\
(0.103)\end{array}$ & $\begin{array}{l}-0.026 \\
(0.087)\end{array}$ & $\begin{array}{c}0.919^{* * *} \\
(0.254)\end{array}$ & $\begin{array}{c}0.126 \\
(0.184)\end{array}$ & $\begin{array}{l}1.110^{* *} \\
(0.431)\end{array}$ & $\begin{array}{c}0.005 \\
(0.003)\end{array}$ \\
\hline Number of children & $\begin{array}{c}1.020 \\
(0.989)\end{array}$ & $\begin{array}{c}0.397 \\
(1.467)\end{array}$ & $\begin{array}{c}2.570 \\
(3.156)\end{array}$ & $\begin{array}{c}0.435 \\
(2.222)\end{array}$ & $\begin{array}{c}4.422 \\
(5.340)\end{array}$ & $\begin{array}{c}0.033 \\
(0.042)\end{array}$ \\
\hline Other parent in household & $\begin{array}{c}0.991 \\
(1.649)\end{array}$ & $\begin{array}{l}-1.277 \\
(2.280)\end{array}$ & $\begin{array}{c}0.599 \\
(5.024)\end{array}$ & $\begin{array}{c}2.612 \\
(2.302)\end{array}$ & $\begin{array}{c}2.926 \\
(8.389)\end{array}$ & $\begin{array}{c}0.014 \\
(0.067)\end{array}$ \\
\hline Parent works full-time & $\begin{array}{c}1.246 \\
(1.226)\end{array}$ & $\begin{array}{c}3.456^{* * *} \\
(1.294)\end{array}$ & $\begin{array}{c}1.479 \\
(5.587)\end{array}$ & $\begin{array}{l}4.389^{* *} \\
(2.159)\end{array}$ & $\begin{array}{l}10.570 \\
(7.099)\end{array}$ & $\begin{array}{l}0.098^{* *} \\
(0.045)\end{array}$ \\
\hline At least one parent has degree & $\begin{array}{c}1.969 \\
(1.340)\end{array}$ & $\begin{array}{c}1.427 \\
(1.334)\end{array}$ & $\begin{array}{c}17.490^{* * *} \\
(4.644)\end{array}$ & $\begin{array}{c}7.231^{* * *} \\
(2.502)\end{array}$ & $\begin{array}{c}28.117^{* * *} \\
(6.687)\end{array}$ & $\begin{array}{c}0.151^{* * *} \\
(0.048)\end{array}$ \\
\hline Own child goes to private school & $\begin{array}{c}1.351 \\
(3.665)\end{array}$ & $\begin{array}{c}6.607 \\
(4.597)\end{array}$ & $\begin{array}{l}54.367^{* *} \\
(21.915)\end{array}$ & $\begin{array}{c}24.098^{* *} \\
(9.614)\end{array}$ & $\begin{array}{c}86.424^{* * *} \\
(28.328)\end{array}$ & $\begin{array}{l}0.432^{* *} \\
(0.168)\end{array}$ \\
\hline High Income & $\begin{array}{c}4.325^{* * *} \\
(1.404)\end{array}$ & $\begin{array}{c}3.994^{* * *} \\
(1.495)\end{array}$ & $\begin{array}{c}19.639^{* * *} \\
(4.727)\end{array}$ & $\begin{array}{l}3.548^{*} \\
(2.152)\end{array}$ & $\begin{array}{c}31.505^{* * *} \\
(6.855)\end{array}$ & $\begin{array}{c}0.213^{* * *} \\
(0.052)\end{array}$ \\
\hline Own child's academic ability & $\begin{array}{c}0.118^{* * *} \\
(0.037)\end{array}$ & $\begin{array}{c}0.036 \\
(0.030)\end{array}$ & $\begin{array}{c}0.406^{* * *} \\
(0.106)\end{array}$ & $\begin{array}{l}-0.070 \\
(0.056)\end{array}$ & $\begin{array}{c}0.490^{* * *} \\
(0.156)\end{array}$ & $\begin{array}{c}0.003^{* * *} \\
(0.001)\end{array}$ \\
\hline Own child's school year & $\begin{array}{l}-0.215 \\
(1.257)\end{array}$ & $\begin{array}{c}1.935 \\
(1.294)\end{array}$ & $\begin{array}{c}3.327 \\
(2.242)\end{array}$ & $\begin{array}{l}-0.386 \\
(1.261)\end{array}$ & $\begin{array}{c}4.661 \\
(4.249)\end{array}$ & $\begin{array}{c}0.033 \\
(0.040)\end{array}$ \\
\hline Own child is male & $\begin{array}{c}1.382 \\
(1.203)\end{array}$ & $\begin{array}{c}3.671^{* * *} \\
(1.328)\end{array}$ & $\begin{array}{l}-3.346 \\
(4.511)\end{array}$ & $\begin{array}{l}-0.021 \\
(2.122)\end{array}$ & $\begin{array}{l}1.685 \\
(6.234)\end{array}$ & $\begin{array}{c}0.063 \\
(0.044)\end{array}$ \\
\hline Age of own child & $\begin{array}{c}0.562 \\
(1.323)\end{array}$ & $\begin{array}{c}-2.622^{* *} \\
(1.258)\end{array}$ & $\begin{array}{l}-4.233^{*} \\
(2.294)\end{array}$ & $\begin{array}{c}0.823 \\
(1.287)\end{array}$ & $\begin{array}{l}-5.470 \\
(4.264)\end{array}$ & $\begin{array}{l}-0.038 \\
(0.040)\end{array}$ \\
\hline Foreign language at home & $\begin{array}{c}2.933 \\
(2.598) \\
\end{array}$ & $\begin{array}{l}4.839^{*} \\
(2.902)\end{array}$ & $\begin{array}{c}2.406 \\
(6.618)\end{array}$ & $\begin{array}{c}5.142 \\
(4.711)\end{array}$ & $\begin{array}{c}15.320 \\
(11.016)\end{array}$ & $\begin{array}{l}0.152^{*} \\
(0.089)\end{array}$ \\
\hline Region FE & Yes & Yes & Yes & Yes & Yes & Yes \\
\hline Sample Mean & 14.64 & 11.90 & 48.64 & 12.32 & 87.50 & 0.01 \\
\hline R-squared & 0.109 & 0.076 & 0.087 & 0.062 & 0.126 & 0.127 \\
\hline Observations & 1509 & 1509 & 1509 & 1509 & 1509 & 1509 \\
\hline
\end{tabular}

Notes: Standard errors in parentheses. ${ }^{*} \mathrm{p}<0.10,{ }^{*} \mathrm{p}<0.05,{ }^{* * *} \mathrm{p}<0.01$. All regressions include a constant. Observations are weighted according to the age and gender of the parent's own child and the education level of the responding parent. The analysis is limited to those individuals for whom the implied perceived returns to material investments are non-negative. For Columns (1)-(4), the dependent variable is the amount spent per month (in $£ s$ ) on the respective category given by the column headings. 'Books' refers to expenditures on books other than school books, while 'Educ. games' denotes spending on educational games and toys. 'Societies' denotes monthly expenditure on sports clubs, music lessons and other societies/clubs, while 'Tuition' refers to private tuition. Column (5) treats the sum of these four expenditure categories (denoted as 'Total') as the dependent variable. In the final column, the dependent variable 'Expenditure' is the extracted first principal component from the responses to the four expenditure categories. 'Perceived returns (material)' refers to the perceived returns to time investments calculated in Section 4.3. 'High income' is a dummy variable equal to 1 if gross annual household income is above the median for our sample, and zero otherwise. 'Own child's academic ability' refers to the academic ability of the child perceived by the parent on a scale of 0 100, where a higher response reflects higher perceived ability. 'Foreign language at home' denotes whether the parent speaks any language other than English at home. 'Sample mean' gives the mean of the dependent variable using only those observations used in the relevant estimation. 
Table A.7: Determinants of school quality investments - Robustness I

\begin{tabular}{|c|c|c|}
\hline & School & Fees \\
\hline Perceived returns (quality) & $\begin{array}{c}0.059 \\
(0.076)\end{array}$ & $\begin{array}{c}107.064^{*} \\
(56.508)\end{array}$ \\
\hline Male parent & $\begin{array}{c}-0.001 \\
(0.043)\end{array}$ & $\begin{array}{c}3.157 \\
(22.168)\end{array}$ \\
\hline Age of parent & $\begin{array}{l}0.005^{*} \\
(0.003)\end{array}$ & $\begin{array}{l}3.504^{* *} \\
(1.364)\end{array}$ \\
\hline Number of children & $\begin{array}{c}0.008 \\
(0.025)\end{array}$ & $\begin{array}{c}-3.423 \\
(11.462)\end{array}$ \\
\hline Other parent in household & $\begin{array}{l}-0.008 \\
(0.055)\end{array}$ & $\begin{array}{c}-3.613 \\
(17.444)\end{array}$ \\
\hline Parent works full-time & $\begin{array}{l}-0.062 \\
(0.042)\end{array}$ & $\begin{array}{l}-10.087 \\
(21.452)\end{array}$ \\
\hline At least one parent has degree & $\begin{array}{c}0.022 \\
(0.037)\end{array}$ & $\begin{array}{c}-1.814 \\
(19.576)\end{array}$ \\
\hline High Income & $\begin{array}{c}0.111^{* * *} \\
(0.039)\end{array}$ & $\begin{array}{c}70.435^{* * *} \\
(18.740)\end{array}$ \\
\hline Own child's academic ability & $\begin{array}{c}0.003^{* *} \\
(0.001)\end{array}$ & $\begin{array}{c}0.605 \\
(0.369)\end{array}$ \\
\hline Own child's school year & $\begin{array}{c}0.015 \\
(0.022)\end{array}$ & $\begin{array}{l}-2.501 \\
(9.583)\end{array}$ \\
\hline Own child is male & $\begin{array}{c}0.017 \\
(0.036)\end{array}$ & $\begin{array}{c}9.473 \\
(16.606)\end{array}$ \\
\hline Age of own child & $\begin{array}{l}-0.026 \\
(0.023)\end{array}$ & $\begin{array}{c}4.506 \\
(10.471)\end{array}$ \\
\hline Foreign language at home & $\begin{array}{c}0.045 \\
(0.046)\end{array}$ & $\begin{array}{c}18.014 \\
(26.130)\end{array}$ \\
\hline Region FE & Yes & Yes \\
\hline Sample Mean & 3.22 & 59.89 \\
\hline R-squared & 0.039 & 0.050 \\
\hline Observations & 1333 & 1406 \\
\hline
\end{tabular}

Notes: Standard errors in parentheses. $* \mathrm{p}<0.10, * * \mathrm{p}<0.05$, $* * * \mathrm{p}<0.01$. Standard errors are clustered at the parent level. All regressions include a constant. Observations are weighted according to the age and gender of the parent's own child and the education level of the responding parent. The analysis is limited to those individuals for whom the implied perceived returns to school quality are non-negative. The dependent variable 'School' is a discrete variable based on the Ofsted rating of the child's school. 'School' takes value 1 if the school is rated as 'Inadequate', 2 if 'Satisfactory/Requires improvement', 3 if 'Good' and 4 if 'Outstanding'. 'Fees' refers to the amount spent per month (in $£$ s) on school fees. 'Perceived returns (school)' refers to the perceived returns to school quality calculated in Section 4.3. 'High income' is a dummy variable equal to 1 if gross annual household income is above the median for our sample, and zero otherwise. 'Own child's academic ability' refers to the academic ability of the child perceived by the parent on a scale of $0-100$, where a higher response reflects higher perceived ability. 'Foreign language at home' denotes whether the parent speaks any language other than English at home. 'Sample mean' gives the mean of the dependent variable using only those observations used in the relevant estimation. 
Table A.8: Determinants of weekly time investments (in minutes) - Robustness II

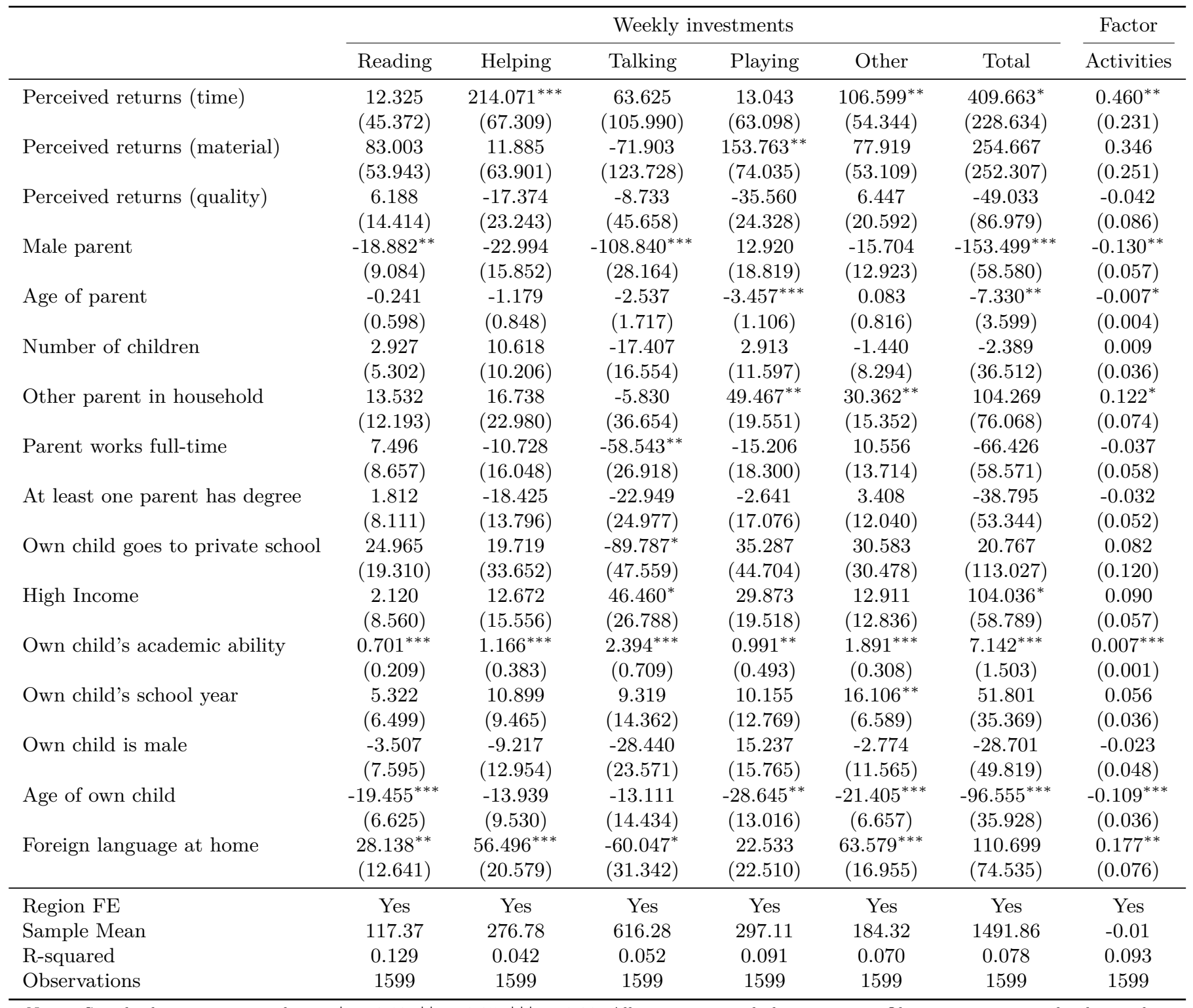

Notes: Standard errors in parentheses. ${ }^{*} \mathrm{p}<0.10, * * \mathrm{p}<0.05, * * * \mathrm{p}<0.01$. All regressions include a constant. Observations are weighted according to the age and gender of the parent's own child and the education level of the responding parent. For Columns (1)-(5), the dependent variable is the number of minutes spent (in minutes) with their own child per week on the five different activities shown in the column headings, while Column (6) treats the sum across all activities as the dependent variable. 'Reading' refers to time spent per week (in minutes) during termtime reading to/with the child, while 'Talking' refers to time spent talking with or listening to the child. 'Helping' denotes time spent helping or teaching the child, and 'Playing' refers to time spent playing with him/her (including sports). 'Other' refers to all other activities related to the child's education. In the final column, the dependent variable 'Activities' is the extracted first principal component from the responses to the five activities. 'Perceived returns (time)' refers to the perceived returns to time investments calculated in Section 4.3. 'High income' is a dummy variable equal to 1 if gross annual household income is above the median for our sample, and zero otherwise. 'Own child's academic ability' refers to the academic ability of the child perceived by the parent on a scale of 0-100, where a higher response reflects higher perceived ability. 'Foreign language at home' denotes whether the parent speaks any language other than English at home. 'Sample mean' gives the mean of the dependent variable using only those observations used in the relevant estimation. 
Table A.9: Determinants of monthly material investments (in £s) - Robustness II

\begin{tabular}{|c|c|c|c|c|c|c|}
\hline & \multicolumn{5}{|c|}{ Monthly investments } & \multirow{2}{*}{$\begin{array}{c}\text { Factor } \\
\text { Expenditure }\end{array}$} \\
\hline & Books & Educ. games & Societies & Tuition & Total & \\
\hline Perceived returns (time) & $\begin{array}{l}-3.758 \\
(8.619)\end{array}$ & $\begin{array}{l}-7.374 \\
(7.288)\end{array}$ & $\begin{array}{c}6.750 \\
(16.278)\end{array}$ & $\begin{array}{l}-18.556 \\
(14.576)\end{array}$ & $\begin{array}{l}-22.937 \\
(32.949)\end{array}$ & $\begin{array}{c}-0.241 \\
(0.282)\end{array}$ \\
\hline Perceived returns (material) & $\begin{array}{l}54.069^{* *} \\
(24.873)\end{array}$ & $\begin{array}{c}31.829^{* * *} \\
(11.613)\end{array}$ & $\begin{array}{c}24.012 \\
(22.122)\end{array}$ & $\begin{array}{c}40.681 \\
(26.779)\end{array}$ & $\begin{array}{c}150.590^{* * *} \\
(57.404)\end{array}$ & $\begin{array}{c}1.619^{* * *} \\
(0.566)\end{array}$ \\
\hline Perceived returns (quality) & $\begin{array}{c}6.073 \\
(4.161)\end{array}$ & $\begin{array}{l}4.639^{*} \\
(2.784)\end{array}$ & $\begin{array}{l}12.310^{*} \\
(7.376)\end{array}$ & $\begin{array}{l}-2.183 \\
(3.863)\end{array}$ & $\begin{array}{c}20.839 \\
(13.768)\end{array}$ & $\begin{array}{c}0.194 \\
(0.121)\end{array}$ \\
\hline Male parent & $\begin{array}{l}-0.201 \\
(1.353)\end{array}$ & $\begin{array}{c}0.350 \\
(1.430)\end{array}$ & $\begin{array}{l}-2.231 \\
(5.353)\end{array}$ & $\begin{array}{c}1.332 \\
(2.852)\end{array}$ & $\begin{array}{l}-0.750 \\
(7.343)\end{array}$ & $\begin{array}{c}0.001 \\
(0.049)\end{array}$ \\
\hline Age of parent & $\begin{array}{c}0.035 \\
(0.089)\end{array}$ & $\begin{array}{l}-0.118 \\
(0.101)\end{array}$ & $\begin{array}{c}0.879^{* * *} \\
(0.234)\end{array}$ & $\begin{array}{c}0.081 \\
(0.171)\end{array}$ & $\begin{array}{c}0.878^{* *} \\
(0.396)\end{array}$ & $\begin{array}{c}0.002 \\
(0.003)\end{array}$ \\
\hline Number of children & $\begin{array}{c}1.558 \\
(1.137)\end{array}$ & $\begin{array}{c}0.966 \\
(1.455)\end{array}$ & $\begin{array}{c}2.640 \\
(2.967)\end{array}$ & $\begin{array}{c}0.710 \\
(2.141)\end{array}$ & $\begin{array}{c}5.874 \\
(5.275)\end{array}$ & $\begin{array}{c}0.052 \\
(0.044)\end{array}$ \\
\hline Other parent in household & $\begin{array}{c}0.166 \\
(1.725)\end{array}$ & $\begin{array}{l}-0.926 \\
(2.195)\end{array}$ & $\begin{array}{l}-0.826 \\
(5.022)\end{array}$ & $\begin{array}{c}2.948 \\
(2.358)\end{array}$ & $\begin{array}{c}1.363 \\
(8.374)\end{array}$ & $\begin{array}{c}0.003 \\
(0.066)\end{array}$ \\
\hline Parent works full-time & $\begin{array}{c}1.428 \\
(1.253)\end{array}$ & $\begin{array}{c}3.757^{* * *} \\
(1.290)\end{array}$ & $\begin{array}{c}0.289 \\
(5.317)\end{array}$ & $\begin{array}{l}4.991^{* *} \\
(2.104)\end{array}$ & $\begin{array}{l}10.465 \\
(6.890)\end{array}$ & $\begin{array}{l}0.104^{* *} \\
(0.045)\end{array}$ \\
\hline At least one parent has degree & $\begin{array}{c}1.624 \\
(1.525)\end{array}$ & $\begin{array}{c}0.923 \\
(1.454)\end{array}$ & $\begin{array}{c}16.990^{* * *} \\
(4.414)\end{array}$ & $\begin{array}{c}7.400^{* * *} \\
(2.470)\end{array}$ & $\begin{array}{c}26.937^{* * *} \\
(6.746)\end{array}$ & $\begin{array}{c}0.137^{* * *} \\
(0.052)\end{array}$ \\
\hline Own child goes to private school & $\begin{array}{c}0.500 \\
(3.489)\end{array}$ & $\begin{array}{c}7.607 \\
(4.989)\end{array}$ & $\begin{array}{l}46.687^{* *} \\
(20.183)\end{array}$ & $\begin{array}{c}22.840^{* *} \\
(8.956)\end{array}$ & $\begin{array}{c}77.635^{* * *} \\
(26.479)\end{array}$ & $\begin{array}{l}0.400^{* *} \\
(0.164)\end{array}$ \\
\hline High Income & $\begin{array}{c}4.339^{* * *} \\
(1.488)\end{array}$ & $\begin{array}{l}3.293^{* *} \\
(1.589)\end{array}$ & $\begin{array}{c}19.361^{* * *} \\
(4.470)\end{array}$ & $\begin{array}{c}3.078 \\
(2.201)\end{array}$ & $\begin{array}{c}30.072^{* * *} \\
(6.842)\end{array}$ & $\begin{array}{c}0.199^{* * *} \\
(0.054)\end{array}$ \\
\hline Own child's academic ability & $\begin{array}{c}0.111^{* * *} \\
(0.037)\end{array}$ & $\begin{array}{l}0.066^{* *} \\
(0.032)\end{array}$ & $\begin{array}{c}0.368^{* * *} \\
(0.102)\end{array}$ & $\begin{array}{l}-0.097 \\
(0.061)\end{array}$ & $\begin{array}{c}0.449^{* * *} \\
(0.157)\end{array}$ & $\begin{array}{c}0.003^{* * *} \\
(0.001)\end{array}$ \\
\hline Own child's school year & $\begin{array}{c}0.340 \\
(1.298)\end{array}$ & $\begin{array}{l}2.668^{* *} \\
(1.309)\end{array}$ & $\begin{array}{l}3.882^{*} \\
(2.222)\end{array}$ & $\begin{array}{c}1.933 \\
(1.877)\end{array}$ & $\begin{array}{l}8.823^{*} \\
(4.789)\end{array}$ & $\begin{array}{c}0.067 \\
(0.043)\end{array}$ \\
\hline Own child is male & $\begin{array}{c}1.686 \\
(1.178)\end{array}$ & $\begin{array}{l}3.424^{* *} \\
(1.342)\end{array}$ & $\begin{array}{l}-3.342 \\
(4.301)\end{array}$ & $\begin{array}{c}1.343 \\
(2.137)\end{array}$ & $\begin{array}{c}3.111 \\
(6.086)\end{array}$ & $\begin{array}{c}0.071 \\
(0.044)\end{array}$ \\
\hline Age of own child & $\begin{array}{l}-0.076 \\
(1.381)\end{array}$ & $\begin{array}{c}-3.355^{* * *} \\
(1.274)\end{array}$ & $\begin{array}{c}-4.742^{* *} \\
(2.247)\end{array}$ & $\begin{array}{l}-1.592 \\
(1.903)\end{array}$ & $\begin{array}{c}-9.765^{* *} \\
(4.843)\end{array}$ & $\begin{array}{c}-0.074^{*} \\
(0.043)\end{array}$ \\
\hline Foreign language at home & $\begin{array}{c}3.215 \\
(2.618)\end{array}$ & $\begin{array}{l}5.546^{*} \\
(2.978)\end{array}$ & $\begin{array}{c}3.678 \\
(6.200)\end{array}$ & $\begin{array}{c}6.714 \\
(4.613)\end{array}$ & $\begin{array}{l}19.153^{*} \\
(10.920)\end{array}$ & $\begin{array}{l}0.179^{* *} \\
(0.090)\end{array}$ \\
\hline Region FE & Yes & Yes & Yes & Yes & Yes & Yes \\
\hline Sample Mean & 14.64 & 11.90 & 48.64 & 12.32 & 87.50 & 0.01 \\
\hline R-squared & 0.086 & 0.070 & 0.086 & 0.064 & 0.118 & 0.111 \\
\hline Observations & 1627 & 1627 & 1627 & 1627 & 1627 & 1627 \\
\hline
\end{tabular}

Notes: Standard errors in parentheses. $* \mathrm{p}<0.10, * * \mathrm{p}<0.05, * * * \mathrm{p}<0.01$. All regressions include a constant. Observations are weighted according to the age and gender of the parent's own child and the education level of the responding parent. For Columns (1)-(4), the dependent variable is the amount spent per month (in $£$ s) on the respective category given by the column headings. 'Books' refers to expenditures on books other than school books, while 'Educ. games' denotes spending on educational games and toys. 'Societies' denotes monthly expenditure on sports clubs, music lessons and other societies/clubs, while 'Tuition' refers to private tuition. Column (5) treats the sum of these four expenditure categories (denoted as 'Total') as the dependent variable. In the final column, the dependent variable 'Expenditure' is the extracted first principal component from the responses to the four expenditure categories. 'Perceived returns (material)' refers to the perceived returns to time investments calculated in Section 4.3. 'High income' is a dummy variable equal to 1 if gross annual household income is above the median for our sample, and zero otherwise. 'Own child's academic ability' refers to the academic ability of the child perceived by the parent on a scale of 0 100, where a higher response reflects higher perceived ability. 'Foreign language at home' denotes whether the parent speaks any language other than English at home. 'Sample mean' gives the mean of the dependent variable using only those observations used in the relevant estimation. 
Table A.10: Determinants of school quality investments - Robustness II

\begin{tabular}{|c|c|c|}
\hline & School & Fees \\
\hline Perceived returns (time) & $\begin{array}{l}-0.125 \\
(0.130)\end{array}$ & $\begin{array}{c}-169.436^{* *} \\
(80.654)\end{array}$ \\
\hline Perceived returns (material) & $\begin{array}{c}0.074 \\
(0.169)\end{array}$ & $\begin{array}{c}173.440 \\
(126.260)\end{array}$ \\
\hline Perceived returns (quality) & $\begin{array}{c}0.077 \\
(0.066)\end{array}$ & $\begin{array}{l}85.648^{*} \\
(49.383)\end{array}$ \\
\hline Male parent & $\begin{array}{c}-0.002 \\
(0.039)\end{array}$ & $\begin{array}{c}14.817 \\
(20.068)\end{array}$ \\
\hline Age of parent & $\begin{array}{l}0.005^{* *} \\
(0.002)\end{array}$ & $\begin{array}{l}2.614^{* *} \\
(1.146)\end{array}$ \\
\hline Number of children & $\begin{array}{c}0.009 \\
(0.023)\end{array}$ & $\begin{array}{c}-4.325 \\
(10.145)\end{array}$ \\
\hline Other parent in household & $\begin{array}{c}-0.004 \\
(0.049)\end{array}$ & $\begin{array}{c}1.169 \\
(15.117)\end{array}$ \\
\hline Parent works full-time & $\begin{array}{l}-0.058 \\
(0.039)\end{array}$ & $\begin{array}{l}-14.021 \\
(20.039)\end{array}$ \\
\hline At least one parent has degree & $\begin{array}{c}0.030 \\
(0.035)\end{array}$ & $\begin{array}{c}3.172 \\
(16.980)\end{array}$ \\
\hline High Income & $\begin{array}{c}0.117^{* * *} \\
(0.036)\end{array}$ & $\begin{array}{c}72.834^{* * *} \\
(16.678)\end{array}$ \\
\hline Own child's academic ability & $\begin{array}{c}0.003^{* * *} \\
(0.001)\end{array}$ & $\begin{array}{c}0.481 \\
(0.336)\end{array}$ \\
\hline Own child's school year & $\begin{array}{c}0.014 \\
(0.018)\end{array}$ & $\begin{array}{l}-0.173 \\
(7.615)\end{array}$ \\
\hline Own child is male & $\begin{array}{c}0.012 \\
(0.033)\end{array}$ & $\begin{array}{c}4.387 \\
(15.441)\end{array}$ \\
\hline Age of own child & $\begin{array}{l}-0.021 \\
(0.019)\end{array}$ & $\begin{array}{c}3.110 \\
(8.574)\end{array}$ \\
\hline Foreign language at home & $\begin{array}{c}0.063 \\
(0.044)\end{array}$ & $\begin{array}{c}27.085 \\
(25.558)\end{array}$ \\
\hline Region FE & Yes & Yes \\
\hline Sample Mean & 3.22 & 59.89 \\
\hline R-squared & 0.047 & 0.055 \\
\hline Observations & 1549 & 1638 \\
\hline
\end{tabular}

Notes: Standard errors in parentheses. ${ }^{*} \mathrm{p}<0.10,{ }^{* *} \mathrm{p}<0.05$,

$* * * \mathrm{p}<0.01$. Standard errors are clustered at the parent level.

All regressions include a constant. Observations are weighted according to the age and gender of the parent's own child and the education level of the responding parent. The dependent variable 'School' is a discrete variable based on the Ofsted rating of the child's school. 'School' takes value 1 if the school is rated as 'Inadequate', 2 if 'Satisfactory/Requires improvement', 3 if 'Good' and 4 if 'Outstanding'. 'Fees' refers to the amount spent per month (in £s) on school fees. 'Perceived returns (school)' refers to the perceived returns to school quality calculated in Section 4.3. 'High income' is a dummy variable equal to 1 if gross annual household income is above the median for our sample, and zero otherwise. 'Own child's academic ability' refers to the academic ability of the child perceived by the parent on a scale of 0-100, where a higher response reflects higher perceived ability.

'Foreign language at home' denotes whether the parent speaks any language other than English at home. 'Sample mean' gives the mean of the dependent variable using only those observations used in the relevant estimation. 


\section{Appendix B: Questionnaires}

\section{B.1 Hypothetical Investment Scenarios}

Next we are interested in your opinion about how important it is for parents to devote time and financial resources to help their children acquire new skills. For this purpose, we will ask you to imagine two average British families, the Jones and the Smiths, who make decisions about how much time and money to devote to their children. More specifically, we will show you different scenarios and ask you what you think the likely yearly earnings of the child will be at age 30. We know these questions are difficult. Please try to consider each scenario carefully and tell us what you believe the likely outcome to be.

Mr and Mrs Jones have one child, John. ${ }^{14}$ John is in Year 3 of primary school ${ }^{15}$, and he attends a popular school, which has been rated as 'Outstanding'. In the KS1 SATs John achieved the expected level. ${ }^{16}$ During school years 3-6, Mr and Mrs Jones can decide how much time to devote to helping John acquire new skills (e.g. by reading to/with John, playing educational games, talking to John, helping John with his school work etc.) and how much money to spend on educational resources which help John acquire new skills (e.g. books, educational games, private tuition etc.). Assuming there is no inflation, what do you expect John's gross yearly earnings to be when he is 30 years old...17

A) if they help John for 0 hours every week to acquire new skills, and they spend £0 every week on educational resources which help John to acquire new skills.

B) if they help John for 0 hours every week to acquire new skills, and they spend £30 every week on educational resources which help John to acquire new skills.

C) if they help John for 3 hours every week to acquire new skills, and they spend £0 every week on educational resources which help John to acquire new skills.

D) if they help John for 3 hours every week to acquire new skills, and they spend £30 every week on educational resources which help John to acquire new skills.

\footnotetext{
${ }^{14}$ Half of the parents in our sample were randomised into seeing a son (John) with the other half seeing a daughter (Jane).

${ }^{15}$ Parents were randomly selected into seeing either a child in Year 3 (primary school) or Year 7 (secondary school) in order to analyse the effect of the timing of investments.

${ }^{16}$ Half of the parents saw a child who achieved the expected level (high initial skill level) and half saw a child who did not (low initial skill level)

${ }^{17}$ Parents saw either low/high time and material investments of 0 hours/3 hours and $£ 0 / £ 30$ respectively (Group 0 ) or low/high time and material investments of 1 hour/4 hours and $£ 10 / £ 40$ respectively (Group 1 ).
} 
Now imagine a different family, the Smiths. In many respects the Smiths are very similar to the Jones. ${ }^{18}$ For example, Mr and Mrs Smith also have one child, Simon, who is in Year 3 of primary school. They live in the same neighbourhood as Mr and Mrs Jones and they have similar levels of income and education. Also, the two children John and Simon have similar levels of intellectual ability and they both achieved the expected level in the KS1 SATs. However, there is one difference. Unlike John's school, which is popular and has been rated as 'Outstanding', Simon's school is not very popular and has only been rated as 'Requires Improvement'. Assuming there is no inflation, what do you expect Simon's gross yearly earnings to be when he is 30 years old...

A) if they help Simon for 0 hours every week to acquire new skills, and they spend $£ 0$ every week on educational resources which help Simon to acquire new skills.

B) if they help Simon for 0 hours every week to acquire new skills, and they spend $£ 30$ every week on educational resources which help Simon to acquire new skills.

C) if they help Simon for 3 hours every week to acquire new skills, and they spend $£ 0$ every week on educational resources which help Simon to acquire new skills.

D) if they help Simon for 3 hours every week to acquire new skills, and they spend $£ 30$ every week on educational resources which help Simon to acquire new skills.

\section{B.2 Parental Investment Questions}

In the following, please think about you and your child.

How much time do you usually spend on each of the following activities during term-time? Please provide time spent in minutes on a typical weekdays and the time spend in minutes on a typical weekend day. If you don't engage in a given activity, please insert 0.

1) Reading to/with child

2) Talking with/listening to child

3) Helping/teaching child

4) Playing with child (including sports)

5) Other activities related to child's education

\footnotetext{
${ }^{18}$ The age, gender and initial skill level of the hypothetical child and the levels of low/high investments seen by parents are kept the same for the two families.
} 
During term-time, how much money do you on average spend (in £s) on the following categories per month for your child? If you don't spend any money in a given category, please insert 0.

1) Books (other than school books)

2) Educational games and toys

3) Sports clubs/music lessons/other societies

4) Private tuition

5) School fees

\section{B.3 Supplementary Mindset Questionnaire}

To what extent do you agree or disagree with the following statements? [1 "Strongly disagree" 2 "Disagree" 3 "Neither agree nor disagree" 4 "Agree" 5 "Strongly agree"]

1) My child develops at his/her own pace and there is not much I can do about that.

2) If my child is not performing well in school, there is a lot I can do to help my child perform better.

3) My child is a certain kind of person, and there is not much that can be done to really change that.

4) Some children get more discouraged by setbacks than others - there is not much I as a parent can do to change that. 


\section{Appendix C: Sample}

Figure C.1: Distribution of household income - Comparison to Family Resources Survey

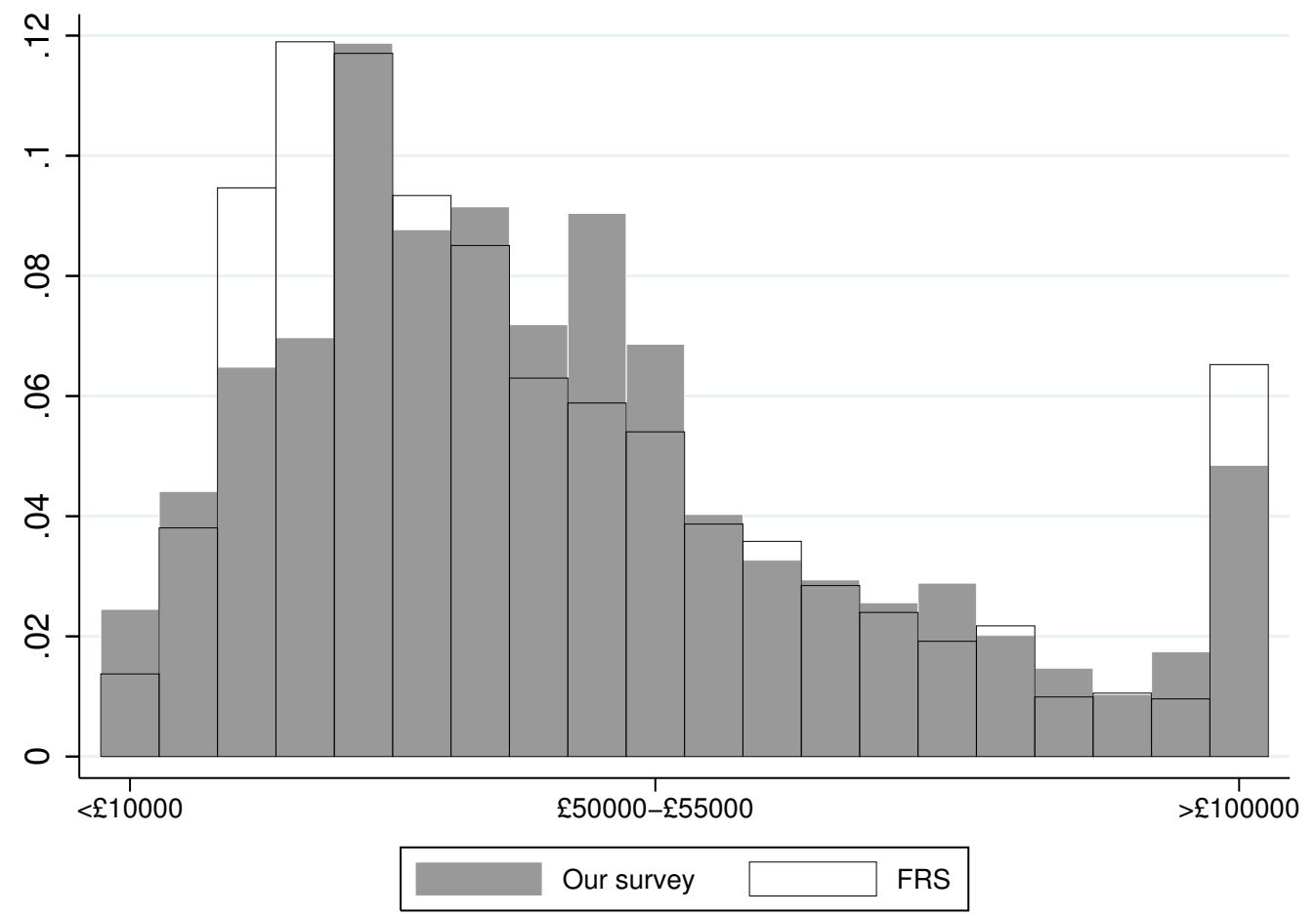

